\title{
Thrust and detachment systems in the Ordenes Complex (northwestern Spain): Implications for the Variscan-Appalachian geodynamics
}

\author{
José R. Martínez Catalán \\ Departamento de Geología, Universidad de Salamanca, 37008 Salamanca, Spain \\ Florentino Díaz García \\ Departamento de Geología, Universidad de Oviedo, 33005 Oviedo, Spain \\ Ricardo Arenas, Jacobo Abati, Pedro Castiñeiras \\ Departamento de Petrología y Geoquímica, Universidad Complutense, 28040 Madrid, Spain \\ Pablo González Cuadra, Juan Gómez Barreiro \\ Departamento de Geología, Universidad de Salamanca, 37008 Salamanca, Spain \\ Francisco J. Rubio Pascual \\ Instituto Geológico y Minero de España, Ríos Rosas 23, 28003 Madrid, Spain
}

\begin{abstract}
The allochthonous complexes of northwestern Iberia consist of a pile of units of Gondwanan and peri-Gondwanan provenance, and include oceanic lithosphere. The units are classified into upper, intermediate (ophiolitic), and basal. We present a detailed geological map and sections across the Ordenes Complex, together with a brief description of its units and a discussion of its structures.

In the upper units, two complete cycles of burial and exhumation have been identified. The first cycle, of Early Ordovician age, records a convergent plate margin, possibly in a peri-Gondwanan domain. The second is Variscan, and the structural evolution of the three groups of allochthonous units reflects progressive accretion to an active orogenic wedge. Continuous understacking of continental and oceanic fragments toward the west began with the upper units and ended with the basal units. The latter represent the outermost margin of Gondwana, and their subduction marked the closure of the intervening ocean, and the change from subduction to a collisional regime. Terrane accretion took place in the Devonian and, during the Late Devonian and the Carboniferous, the deformation progressed inboard of the Gondwana margin.

Variscan emplacement of the allochthonous units occurred in two successive thrusting episodes. The first placed the basal units over the sedimentary cover of the Gondwana margin in what seems to follow a normal sequence of thrusting. The second carried the upper and ophiolitic units on top of the previous nappe pile and has an out-of-sequence character.

A possible correlation of the Early Ordovician convergence, early Variscan accretion, subsequent oceanic closure, continent-continent collision, and renewed thrust activity during the late Carboniferous in northwestern Iberia is established with the Taconian, Acadian, and Alleghanian orogenies in the Appalachians.
\end{abstract}




\section{INTRODUCTION}

The Iberian Massif is part of a tight orocline known as the Ibero-Armorican arc (Bard et al., 1971; Ribeiro et al., 1995), which represents the western part of the European Variscan Belt. Variscan structures were once continuous between northern Iberia and the Armorican Massif, and, apparently, the belt extended southward into northern Africa. A late Paleozoic reconstruction of the continental masses (i.e., at the end of the Variscan cycle) places Iberia adjacent to the Grand Banks of
Newfoundland (Fig. 1) and close to the junction of three important Paleozoic belts: the Appalachians, the Caledonides, and the Variscides (Lefort, 1989).

Although the position of Iberia at the end of the Proterozoic is not precisely located, there is general agreement that it occupied a marginal area in northern Gondwana. During the Late Proterozoic, this area was an active continental margin (Murphy and Nance, 1991; Ochsner, 1993) and underwent the Cadomian orogeny. Cadomian activity was followed by Cambrian-Ordovician continental rifting, which resulted in the pulling apart of the

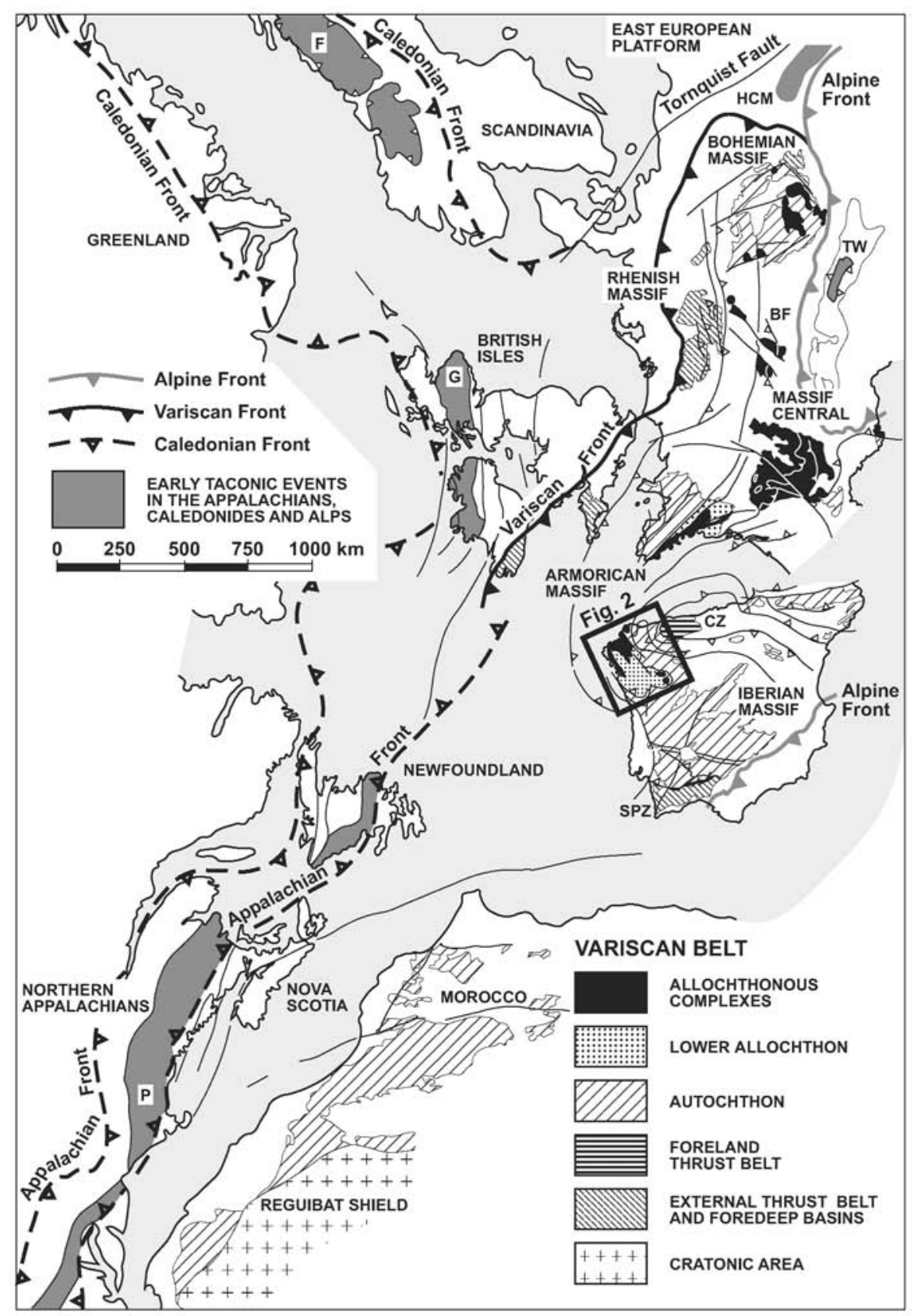

Figure 1. Sketch showing position of Iberia in relation with Appalachian, Caledonian, and Variscan Belts. Abbreviations: BF, Black Forest; CZ, Cantabrian zone; F, Finnmarkian; G, Grampian; HCM, Holy Cross Mountains; P, Penobscottian; SPZ, South Portuguese zone; TW, Tauern Window. Modified from Neuman and Max (1989), with data from Lefort (1989), Franke (1989), and Martínez Catalán et al. (1999). 
Avalon microcontinent and other peri-Gondwanan terranes from the Gondwana mainland and the opening of the Rheic oceanic domain (Fortey and Cocks, 1988; Soper, 1988).

The Rheic oceanic realm became subsequently closed during convergence between Laurentia and Gondwana. Convergence started in the Early Ordovician in the Appalachians (Keppie, 1989; Neuman and Max, 1989; Cawood et al., 1995; Hibbard and Samson, 1995) and proceeded during the Paleozoic, finally resulting in the collision of both continents. Convergence and collision gave rise to the Variscan and Appalachian orogenic belts.

Relicts of the peri-Gondwanan terranes and of the Rheic lithosphere have been preserved in five allochthonous complexes in northwestern Iberia (Fig. 2). This chapter describes and compares the structural history of the individual tectonic units of one of them, the Ordenes Complex, and focuses on their stacking and emplacement on top of the autochthonous northern Gondwana margin. Ductile to brittle structures are described and interpreted, and the role of extensional structures is evaluated. Particular attention is paid to the large-displacement thrust faults responsible for the final emplacement of most of the complex.

The tectonometamorphic history of the different units sheds light on the geodynamic history of the Gondwana-Laurentia convergence. The implications in the orogenic evolution on both sides of the present North Atlantic are discussed.

\section{GEOLOGIC SETTING}

Most of the Iberian Massif has Neoproterozoic-early Paleozoic basement derived from northern Gondwana, as shown by the identification of Cadomian (Pan-African) events, and by the similarity in the oldest ages obtained from upper intercepts and inherited zircons from Iberian orthogneisses and northern Gondwana basement. Ages range between 2.7 and 1.8 Ga (Kuijper, 1980; Lancelot et al., 1985; Peucat et al., 1990; Gebauer, 1993) and are similar to those of the western African craton (Bessoles, 1977; Caby, 1989).

The Iberian Massif is essentially composed of rocks with Gondwanan affinity: the Cadomian basement and the Paleozoic sedimentary sequences, intrusives, and volcanics formed at its northern continental margin. This margin seems to have been predominantly passive from the Cambrian to the SilurianDevonian boundary. This is suggested by the shallow-water platform character of most stratigraphic units, and by the continuity in the sedimentation, which in places continued to the Early Devonian.

The Gondwanan provenance seems clear for the foreland thrust belt of northern Iberia (the Cantabrian zone; see Figs. 1 and 2), and for most of the internal zones, characterized by penetrative ductile deformation, Barrovian-type metamorphism, and large volumes of synkinematic to postkinematic granitoids. Conversely, a Gondwanan provenance seems doubtful for an amphibolitic belt in southwestern Iberia (the BejaAcebuches ophiolites), for the basement of the terrane occurring south of the ophiolite (the South Portuguese zone), having age and facies similar to the Rhenohercynian zone of central Europe (Franke, 1989), and for some of the units that crop out in the allochthonous complexes in the northwest, the object of this contribution.

The allochthonous complexes crop out in five synforms or structural basins as megaklippen in Galicia (northwest Spain) and northern Portugal (Fig. 2). They consist of a pile of units that were stacked, thinned, and dismembered during the Variscan deformation (Arenas et al., 1986; Martínez Catalán et al., 1997; Dallmeyer et al., 1997).

Ordenes ( 135 by $75 \mathrm{~km}$ ) is the largest of the klippen and contains representatives of all different types of allochthonous units. Detailed descriptions and interpretations of many of its units have been published elsewhere (Van Zuuren, 1969; Marquínez García, 1984; Díaz García, 1990; Arenas et al., 1995, 1997; Martínez Catalán et al., 1996; Abati et al., 1999; Díaz García et al., 1999a, 1999b). Plate 2 shows a detailed geological map of the complex, and Plate 3 depicts an idealized composite of nine geological sections through the different allochthonous units, and gives an idea of the structural style, showing the main crosscutting relationships among structures.

The allochthonous complexes were thrust over the sedimentary cover of the passive continental margin of Gondwana. This cover was in turn detached, giving rise to the lower allochthon (the paraautochthon of Ribeiro et al., 1990), which is commonly referred to as the schistose domain (Marquínez García, 1984; Farias et al., 1987). The ensemble formed by the lower allochthon and the complexes was carried inboard onto the autochthonous Paleozoic sequence of Gondwana (see González Clavijo and Martínez Catalán, this volume). The autochthon is commonly repeated by recumbent folds and thrusts. However, we maintain the term autochthon because the sequences in it were deposited over the same basement upon which they now rest. The lower allochthon was part of the same continental margin, but occupied an external position relative to the autochthon (Farias et al., 1987).

\section{ALLOCHTHONOUS UNITS AND THEIR INTERNAL STRUCTURE}

The complexes consist of several allochthonous units, which are characterized by a lithologic association and a particular tectonometamorphic evolution. The units are tectonic in character: they are separated from each other by faults, either thrusts or extensional detachments. The units are grouped according to their lithologic affinities and their relative position in the original nappe pile. Further subdivision can be done based on the lithologies and the pressure-temperature $(P-T)$ conditions of the metamorphic evolution of the units.

The Ordenes Complex shares with other Iberian complexes the types of allochthonous units and their order of stacking, which although generally consistent, may be locally modified by tectonic mixing in thrust zones. Three groups, basal, intermediate, and upper, are described from bottom to top in ascending 


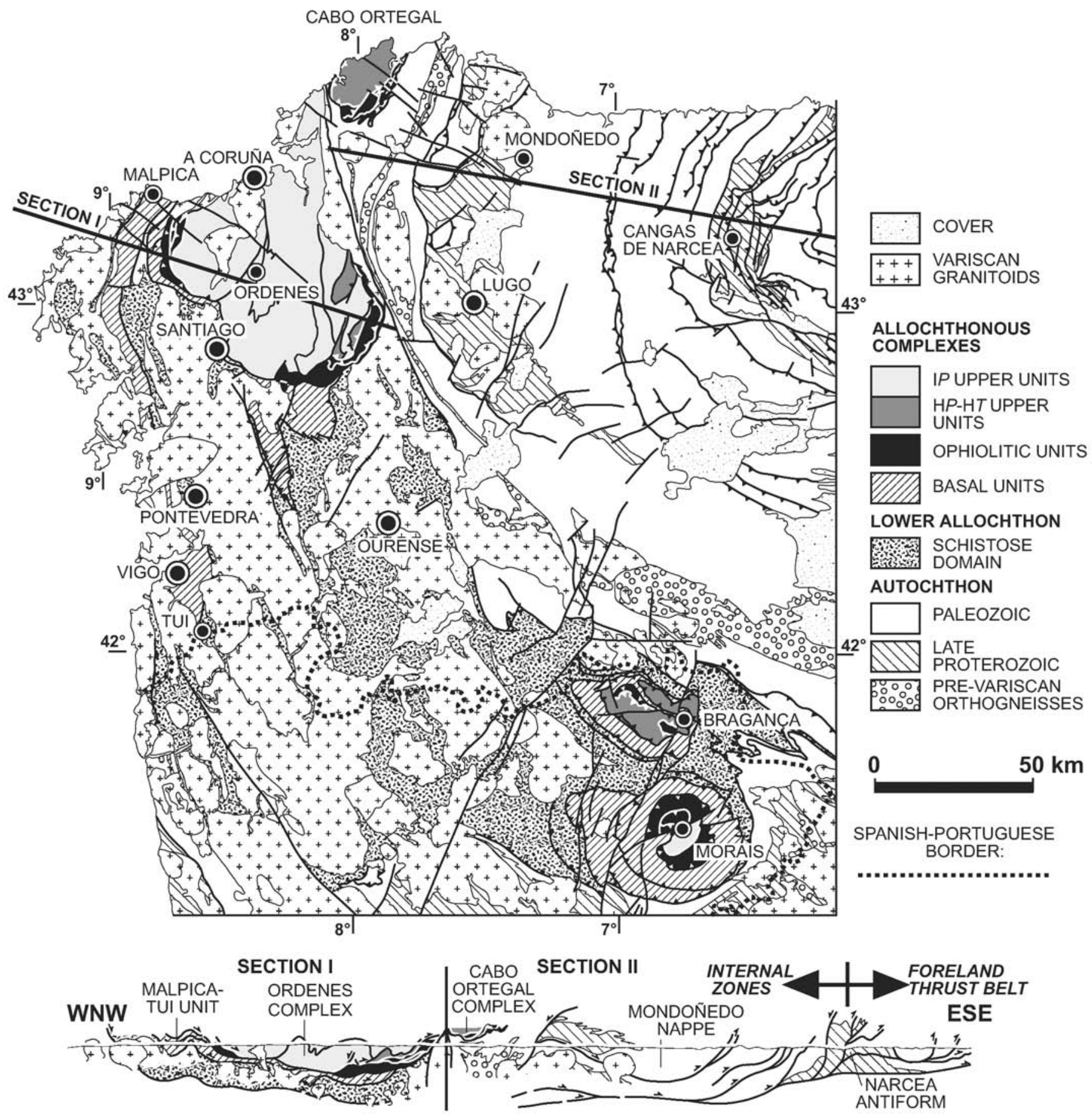

Figure 2. Geological map and composite cross section of northwestern Iberia, showing allochthonous complexes and their groups of units. For location, see Figure 1. IP, intermediate pressure; $\mathrm{H} P$-HT, high-pressure-high temperature. 
structural order, together with the individual units constituting them. The intermediate units show ophiolitic affinities and are referred to as the ophiolitic units. They are interpreted as the suture separating two main paleogeographic realms.

\section{Basal units}

The lowermost units crop south and west of the Ordenes Complex, and continue to the west in the Malpica-Tui unit (Fig. 2), the structure and evolution of which are described in LlanaFúnez and Marcos (this volume).

The basal units consist of schists and paragneisses alternating with felsic and mafic igneous rocks. The metasediments are derived from graywackes and pelites, which, together with their monotonous character, suggest a relatively distal depositional environment. Granitic and peralkaline orthogneisses have yielded ages of 480-460 Ma (Rb-Sr whole rock, Van Calsteren et al., 1979; García Garzón et al., 1981; U-Pb, zircon, Santos Zalduegui et al., 1995). The magmatism reflects an Ordovician episode of rifting (Ribeiro and Floor, 1987; Pin et al., 1992) that probably resulted in the pulling apart of a peri-Gondwanan terrane. However, the basal units are thought to have remained attached to Gondwana, because no ophiolites separate them from the underlying sequences with Gondwanan affinities.

The basal units are considered allochthonous because there is a dramatic change in the metamorphic grade and evolution between them and their substratum: the basal units record a high- $P$ regional metamorphism not found in the lower allochthon or in the autochthon. Representing the edge of the margin formed after the opening of an ocean, these units underwent westward subduction (in present coordinates) between 380 and $365 \mathrm{Ma}$, during the closure of the oceanic domain. The subduction of the outermost edge of Gondwana took place under an accretionary wedge, built just before and consisting of a pile formed by the ophiolitic and upper units (Arenas et. al., 1995; Martínez Catalán et al., 1996).

Forcarei, Lalin, and Santiago units. In the south of the Ordenes Complex, the basal units form the core of two late synforms in Lalín and Forcarei, where their lower limit is the LalínForcarei thrust, and the upper one, the Pico Sacro detachment. In the west, they surround the complex from Santiago to the coast. Here, the Pico Sacro detachment is the lower limit, whereas a thrust fault constitutes its upper boundary. This map pattern permits the identification of three main basal units: Forcarei, Lalín, and Santiago, separated by granitoids and the Pico Sacro detachment. The Santiago unit was overthrust by a small tectonic slice, called the Agualada unit, and the Lalín unit is locally structurally overlain by an ultramafic sheet, the Campo Marzo unit (Plates 2 and 3; Fig. 3).

The basal units are folded by a large recumbent anticline (Plate 3, section 5), the lower limb of which is affected by the Lalín-Forcarei thrust, a ductile fault with eastward movement. The fold hinge occurs north of Lalín (Plate 2), and its axis plunges $10^{\circ}-20^{\circ}$ to the northwest. A band of amphibolites can be mapped to the south and southwest of Lalín, and to the west of Forcarei (Plate 2), delineating the overturned limb of the anticline, which attains a length of nearly $30 \mathrm{~km}$. Its normal limb is also defined by the amphibolites and felsic orthogneisses (Plates 2 and 3, section 5; Fig. 4) and can be traced westward to the Santiago unit, in the west border of the complex.

In the hinge zone, a medium-grained foliation $\left(\mathrm{S}_{2}\right)$ is parallel to the bedding and is folded with it. This foliation is characterized by the synkinematic growth of albite porphyroblasts. An earlier, fine-grained cleavage $\left(\mathrm{S}_{1}\right)$ is preserved as oriented microinclusions in the albite porphyroblasts. $P-T$ estimates for these microinclusions $\left(500{ }^{\circ} \mathrm{C}, 15-17 \mathrm{kbar}\right)$ indicate that the early fine-grained foliation developed in high- $P$ metamorphic conditions (Fig. 5), and is interpreted as the fabric contemporaneous with the subduction of the basal units (Arenas et al., 1995). Similar $P-T$ conditions have been calculated in eclogites of the Santiago unit (Rubio Pascual et al., this volume). The high- $P$ event ended ca. 374-365 Ma (Van Calsteren et al., 1979; Santos Zalduegui et al., 1995; Rb-Sr age of posteclogitic white micas in the Malpica-Tui unit). The different $P-T$ conditions estimated from the two limbs of the recumbent anticline were interpreted by Martínez Catalán et al. (1996) to reflect a westward polarity for the early Variscan subduction.

Other foliations overprint $S_{2}$, the fabric folded by the recumbent anticline. They were mostly developed at its reverse and normal limbs, and an axial planar foliation can be identified at its hinge zone. The younger foliations are collectively termed $\mathrm{S}_{3}$, because they are roughly contemporaneous, even though their origin varies.

At the hinge zone, $S_{3}$ is probably related to the recumbent folding. In the overturned limb of the anticline $S_{3}$ transects $S_{2}$, dipping $10^{\circ}-20^{\circ}$ steeper to the west (when the effects of late folding are removed). In the basal part of Lalín, this fabric is fine grained and is rotated into parallelism with the Lalín-Forcarei thrust (Plate 3, section 5), indicating a relationship between the $\mathrm{S}_{3}$ and thrusting. The thrust is a 40-80-m-thick shear zone with mylonites and ultramylonites, and separates the basal units in the Lalín and Forcarei synforms from the lower allochthon. Rocks of both units are mylonitized. Thin layers of mylonitic quartzite occur in the shear zone and were considered to mark the thrust surface by Hilgen (1971). They have an elongated texture and show a stretching lineation, which is variably oriented due to later folding. Quartz c-axis fabrics are of the single girdle type or show the axes at high angles to the mylonitic foliation, with maxima normal to it (Díaz García, 1993). The single girdle types, when oblique to the foliation, provide kinematic criteria for the motion of the thrust sheet (Bouchez et al., 1983). The east-west attitude of the lineation southwest of Lalín is considered little modified by younger folding, because it occurs at the hinge zone of the Lalín synform, which is a rather open fold. There, the quartz c-axis fabrics indicate a top-to-the-east sense of motion, which is consistent with S-C structures and asymmetric sigmoidal boudinage in the shear zone. 


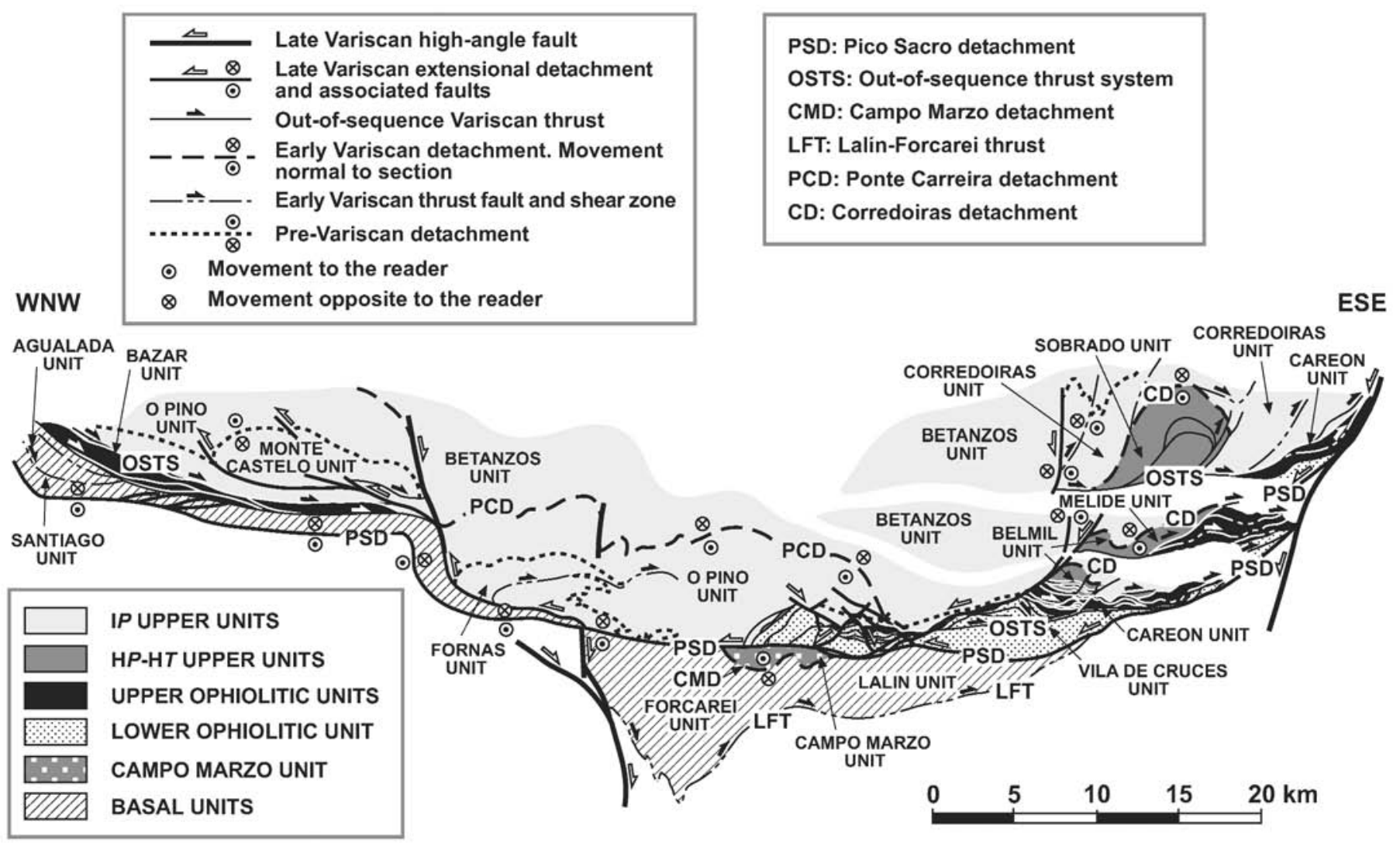

Figure 3. Structural sketch of Ordenes Complex based on Plate 3, showing groups of allochthonous units and different types of faults separating units. $\mathrm{I} P$, intermediate pressure; $\mathrm{H} P$-HT, high-pressure-high temperature.

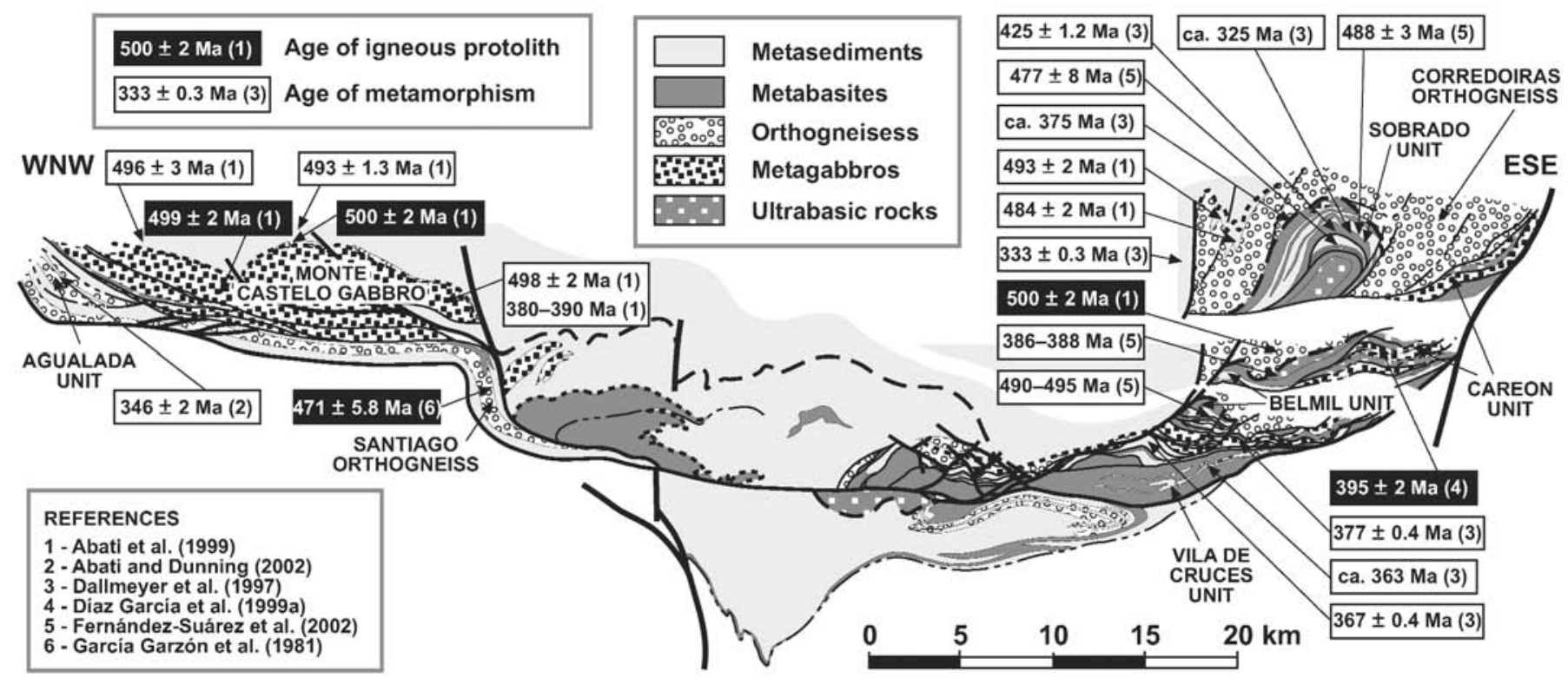

Figure 4. Distribution of main lithologic types in Ordenes Complex, and published isotopic ages of igneous protoliths (black) and regional fabrics (white). Fault types as in Figure 3. 


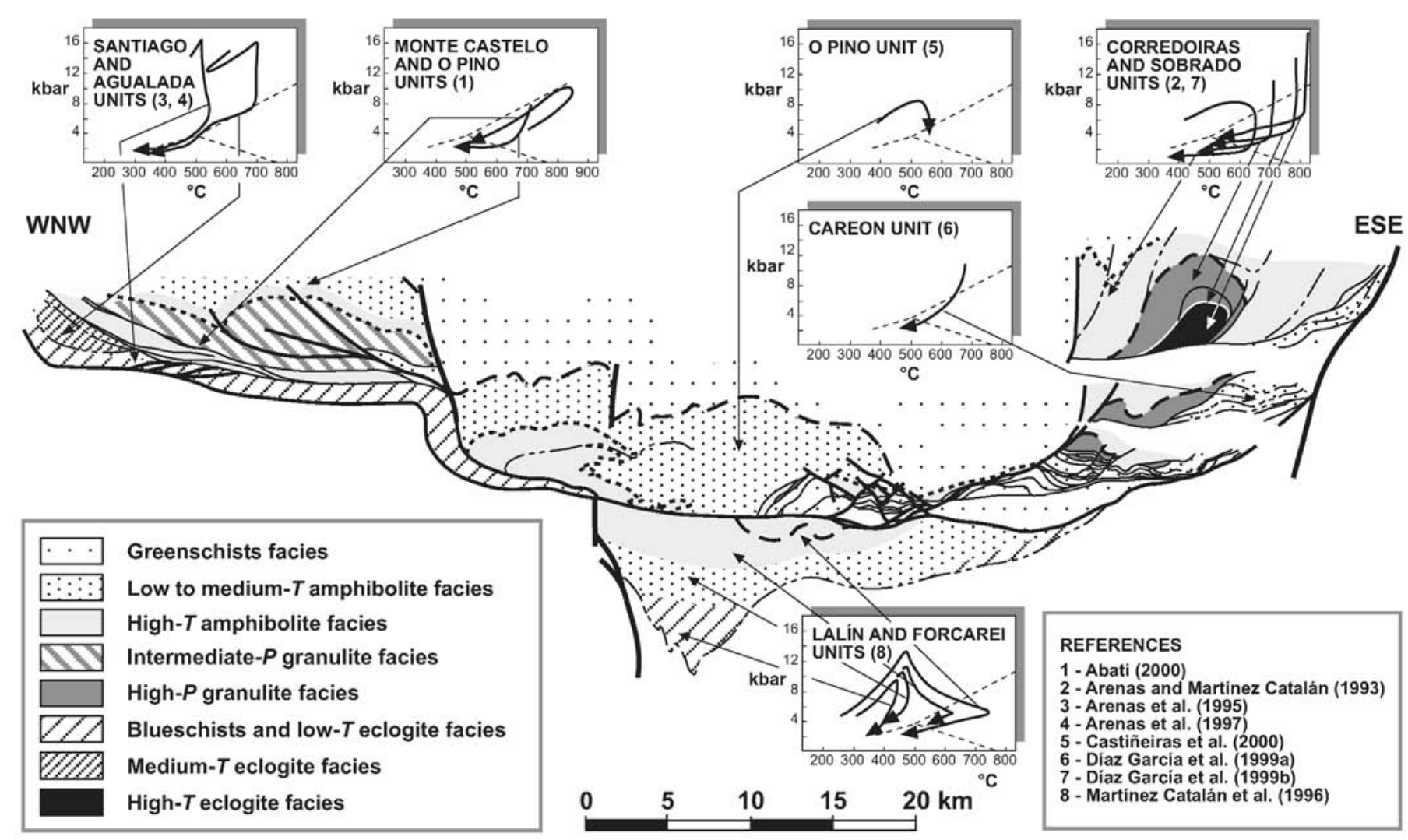

Figure 5. Distribution of main types of metamorphic facies in Ordenes Complex, and published pressure-temperature $(P-T)$ paths for several units. Dashed lines in $P-T$ diagrams represent aluminum silicate phase diagram after Holdaway (1971). Fault types as in Figure 3.

In the normal limb of the recumbent anticline, the foliation is a low- to high- $T$ fabric that shows an upward increase in metamorphic grade (Arenas et al., 1995). The lower grade $S_{2}$ is folded by the anticline, but at structurally higher levels a synkinematic recrystallization took place after the fold had been formed, giving rise to a medium- to coarse-grained foliation $\left(\mathrm{S}_{3}\right)$. This foliation is parallel to the lower grade fabric, and seems induced by the emplacement of a hot overlying slice, the Campo Marzo unit. The metamorphic gradient is inverted (Fig. 5 ) in the northern parts of the Lalín and Forcarei units, and the isograds crosscut the recumbent folds and the Lalín-Forcarei thrust (Martínez Catalán et al., 1996). The $P-T$ paths close to the Campo Marzo unit show the strong heating undergone by the upper part of the Lalín and Forcarei units during decompression (Fig. 5).

Agualada and Campo Marzo units. In the northwest, around Agualada, a migmatitic basal unit was transported on top of another basal unit of lower metamorphic grade by a thrust fault. $P$-T estimates on eclogitic lenses yield temperatures of 720 ${ }^{\circ} \mathrm{C}$ and a minimum pressure of 15 kbar (Arenas et al., 1997; see Fig. 5). Discontinuous lenses of ultramafics at the bounding fault and in a narrow shear zone inside the high-grade unit point to the imbricate character of thrusting and indicate that the mantle was involved with it.

A larger outcrop of ultramafic rocks occurs in Campo Marzo, northwest of Lalín (Plates 2 and 3, section 5). These rocks were probably derived from the hot mantle wedge above the subducted basal units (Arenas et al., 1995, 1997), and the contact with the underlying basal units is a folded low-dipping fault, the Campo Marzo detachment. Martínez Catalán et al. (1996) interpreted it as an extensional fault, based on its direction of motion, which is roughly north-south, parallel to the orogenic trend (Fig. 3). Its emplacement on top of the relatively cold basal units provoked a heat transfer that gave rise to an inverted metamorphic gradient, as seen in the Santiago unit, and in the northern parts of the Lalín and Forcarei units. The mantle rocks induced the widespread development of migmatites (Plates 2 and 3, sections 5-7). U-Pb dating of monazites from the Agualada migmatitic paragneisses has yielded a concordant age of 346 \pm 2 Ma (Abati and Dunning, 2002).

To provoke such a thermal imprint, the ultramafic slice must have been extensive. However, this slice was dismembered by subsequent thrusting, well characterized in the overlying units (see following). In addition, a small part could be 
hidden by the Pico Sacro detachment (Plate 3; Fig. 3), a late extensional fault.

\section{Ophiolitic units}

The units occupying a structurally intermediate position crop out in the periphery of the Ordenes Complex, in three different and tectonically imbricated slices known as the Vila de Cruces (south), Careón (southeast), and Bazar (west) units (Plates 2 and 3; Fig. 3). The latter two have similar rock types and, because Careón overlies the Vila de Cruces unit, they are often called the upper ophiolitic units. Vila de Cruces is then referred to as the lower ophiolitic unit (Fig. 3).

Vila de Cruces unit. The lowermost ophiolitic unit consists of greenschist facies mafic rocks (greenstones) and metapelites, with rare felsic orthogneisses, serpentinites, and cherts. Mesozonal relics in the mafic rocks indicate that an earlier amphibolite facies regional metamorphic event affected parts of the unit. In addition, a low- to intermediate- $T$ and high- $P$ metamorphic gradient has been identified in the metapelites.

Two phases of recumbent folding, the first with isoclinal structures of kilometer scale, were followed by the development of an east-southeast-directed thrust, which resulted in structural repetition of lithologies. Several duplexes developed during thrusting (Plate 3; Figs. 3 and 6). The greenschist facies foliation related to the second-phase recumbent folds has been dated as 363-367 Ma (Dallmeyer et al., 1997; ${ }^{40} \mathrm{Ar} /{ }^{39} \mathrm{Ar}$, whole-rock and muscovite concentrates in phyllites; see Fig. 4).

The deformation is so penetrative that it is difficult to establish the protoliths of the greenstones. However, for those interbedded with the metasediments, a volcanic origin seems reasonable. On these grounds, their association with seemingly distal metasediments and ultramafics suggests that they may belong to an ophiolitic suite, even though this unit may not represent a typical ophiolite. The presence of orthogneisses and the metamorphic evolution of the metapelites, which compares to that of the basal units, suggest that the Vila de Cruces unit represents the transition between the outermost continental crust of Gondwana and the oceanic lithosphere of the overlying ophiolitic units.

Careón unit. This unit represents the basal parts of an ophiolitic sequence, characterized by the abundance of pegmatitic gabbros and diabase dikes, and by the lack of layered gabbros. The mafic rocks, their igneous textures either preserved or transformed into flasergabbros and amphibolites, are underlain by ultramafics, and this sequence was repeated by east-directed thrust faults (Plate 3, sections 1 and 2; Fig. 3) in three main thrust sheets with abundant internal imbrication (Díaz García et al., 1999a).

Although the ultramafic section is characterized by a high degree of serpentinization, a harzburgitic composition can be inferred where alteration is minor. The transition between harzburgite and gabbro is abrupt, although locally the mafic-ultramafic boundary is intruded by numerous gabbroic and diabase dikes. It is considered the "petrological" paleo-Moho and occurs along a surface without significant deformation and mostly parallel to the foliation in the mafic and ultramafic rocks.

The gabbroic section consists of a complex network formed by multiple intrusions of gabbroic rocks, wehrlite, and wehrlitegabbro transitional compositions, and diabase to pegmatoid dikes. Gabbroic rocks outside ductile shear zones remain mostly undeformed and retain their igneous texture. The most common type is a medium- to coarse-grained isotropic metagabbro, commonly intruded by pegmatoid and diabase dikes. A weakly foliated plagioclase-rich gabbro gave a concordant age of $395 \pm$ 2 Ma (Díaz García et al., 1999a; U-Pb geochronology in zircons), which is considered a protolith age (Fig. 4). Because plagioclase-rich gabbros are common components of the ophiolite, the age provides evidence for oceanic crust generation in this peri-Gondwanan domain by Early Devonian time.

Complete transformation of gabbroic rocks into well-foliated amphibolites occurs at the boundary between the main thrust sheets, where garnetiferous amphibolites appear discontinuously in the hanging wall. In the footwall, garnetiferous amphibolites occur attached to the allochthonous ultramafic rocks showing granonematoblastic textures and a penetrative foliation. Garnet growth is synkinematic with the foliation. Inside each of the sheets, the garnetiferous amphibolites give way with increasing depth to epidote-amphibolite facies metabasic rocks. Corundum-bearing metabasic rocks occur immediately beneath the ultramafic rocks of the uppermost thrust sheet (Díaz García et al., 1999a). The preservation of a high- $T$ mineral such as corundum in amphibole-rich metabasic rocks attests to an intense dynamothermal metamorphism (sanidinite facies of Yardley, 1989) close to the overlying ultramafic sheet. The vertical distribution of both garnet and corundum points to an inverted metamorphic gradient in the upper parts of the sheets, similar to that described in thrust-related metamorphic soles (Jamieson, 1986).

The $P$ - $T$ conditions ranging between 625 and $680{ }^{\circ} \mathrm{C}$ and 11.1 and 11.9 kbar have been obtained on the peak mineral assemblage of the garnet amphibolites by Díaz García et al. (1999a). A well-foliated garnet amphibolite was dated by the ${ }^{40} \mathrm{Ar} /{ }^{39} \mathrm{Ar}$ method (Dallmeyer et al., 1997), obtaining a plateau isotopic correlation age of $376.8 \pm 0.4 \mathrm{Ma}$, which represents a cooling age following the amphibolite facies metamorphism (Fig. 4). This age is similar to that obtained in Cabo Ortegal and the Portuguese Complexes by the same method (390-380 Ma; Dallmeyer and Gil Ibarguchi, 1990; Dallmeyer et al., 1991).

Subsequently, retrogressive greenschist facies metamorphism developed throughout the Careón unit (Fig. 5) and is especially concentrated close to the thrust surfaces. It developed serpentinite mylonites in the hanging walls, and well-foliated metabasites with fine-grained nematoblastic textures and pervasive shear bands in the footwalls.

Thrust-related shear zones are characterized by intensely foliated rocks, meter-scale tight isoclinal folds, and two systems of shear bands. An east-west stretching lineation is defined by recrystallized olivine in the ultramafic rocks, the foliation of which 
developed at the highest temperatures, in the amphibolites and in the serpentinite mylonites. Fold asymmetry, $\sigma$-type porphyroclast systems, and shear bands give a consistent top-to-the-east sense of displacement for the two main thrusts repeating the mafic-ultramafic sections. The existence of mantle-rooted thrusts and related metamorphic soles points to a relationship with a subduction environment, the kinematics of which agree with the westward polarity inferred in the basal units from the metamorphic conditions. In contrast, the later thrusts separating the Careón unit from the adjacent ones, and several related imbricate faults, show top-to-the-southeast motion.

Bazar unit. The Bazar unit crops out in the west part of the Ordenes Complex (Plates 2 and 3; Fig. 3); this unit shares many characteristics with those of Careón. It represents the lower part of an ophiolitic sequence composed of serpentinized dunites and isotropic gabbros with minor intrusions of pegmatoid gabbros. The isotropic gabbros exhibit a tholeiitic character, with flat chondrite-normalized rare earth element patterns, and show similarities to volcanic arc basalts, based on positive anomalies in light lithophile elements and marked negative $\mathrm{Nb}$ anomaly (Díaz García, 1990). The deformation is heterogeneous, with ductile shear zones separating weakly deformed gabbros and repeating the mafic and ultramafic association. Metamorphic conditions reached the granulite facies and changed along the deformation to the amphibolite and greenschist facies.

\section{Upper units}

The units that structurally overlie the ophiolites are collectively termed the upper units, but can be subdivided into two subgroups of unequal area extent. High- $P$-high- $T$ units occur as small massifs and kilometer-scale lenses in the southeast of the Ordenes Complex (Plate 2). These units appear discontinuously overlying the ophiolites of the Careón unit, and occupy a structurally low position among the upper units considered as an ensemble (Fig. 3). The more important are the Sobrado, Belmil, and Melide units (Plates 2 and 3, sections 1-3). The high- $P$-high- $T$ units are well represented in the Cabo Ortegal Complex, and their structure is described in Marcos et al. (this volume).

Structurally above the high- $P$-high- $T$ units is a group of intermediate- $P$ units. They are by far the more extensive, occupying the central part of the Ordenes Complex and representing two-thirds of its outcropping surface.

The boundary between intermediate- $P$ and high- $P$-high- $T$ upper units is a low-dipping fault known as the Corredoiras detachment, that appears folded and limits the tectonic windows of Sobrado and Belmil (Plate 3; Fig. 3). The fault includes a 300-600-m-thick mylonitic shear zone, with kinematic criteria indicating top-to-the-north or northeast motion (Díaz García et al., 1999b). The Corredoiras detachment has an extensional character, as shown by the difference in the peak pressure between its hanging wall (the intermediate- $P$ Corredoiras unit) and its footwall (the high- $P$-high- $T$ Sobrado, Melide, and Belmil units; see Fig. 5). A hornblende ${ }^{40} \mathrm{Ar} /{ }^{39} \mathrm{Ar}$ analysis carried out in an amphibolite of the mylonitic zone yielded an age of 375 Ma (Dallmeyer et al., 1997).

The ensemble of the upper units was thrust over the ophiolitic units. However, earlier detachments, folds, and thrusts have been identified, making the structural evolution of the upper units one of the most complicated found so far in the Iberian Massif. This complexity derives from the fact that the upper units have undergone an older, Early Ordovician tectonothermal event, overprinted by a long Variscan deformational history.

High-P-high-T upper units: Sobrado, Melide, and Belmil. These units consist of paragneisses and basic and ultrabasic metaigneous rocks. The characteristic rocks are metabasites, commonly garnet-clinopyroxene granulites and eclogites, retrograded to the amphibolite facies (Vogel, 1967; Hubregtse, 1973). Gabbros occur in several stages of transformation, from practically undeformed and scarcely affected by the metamorphism, to coronitic metagabbros and high- $P$ granulites. In the less deformed gabbros, subophitic and diabase textures have been preserved, indicating an emplacement at relatively shallow crustal levels (Arenas and Martínez Catalán, this volume).

The tectonothermal evolution of these units include an older high- $P$ granulite to eclogite facies metamorphism (475-495 Ma, Fernández-Suárez et al., 2002; see Figs. 4 and 5), followed by decompression and partial melting and then, successively, by a penetrative mylonitization in the amphibolite facies, recumbent folding, and thrusting in the greenschist facies (Vogel, 1967; Marcos et al., 1984; Gil Ibarguchi et al., 1990; Arenas, 1991; Girardeau and Gil Ibarguchi, 1991; Mendia Aranguren, 1996).

Two thrust faults have been identified within the Sobrado unit, separating three tectonic slices (Plate 3, section 1; Fig. 3) with different peak metamorphic conditions (Martínez Catalán and Arenas, 1992; Arenas and Martínez Catalán, this volume). The upper slice underwent the lower metamorphic conditions, in the high- $P$ part of the granulite facies, whereas the lower slice attained high- $T$ eclogitic conditions. A low-grade ultramylonitic gneiss probably marking a thrust fault within the upper slice yielded a muscovite ${ }^{40} \mathrm{Ar} /{ }^{39} \mathrm{Ar}$ age of ca. $325 \mathrm{Ma}$ (Dallmeyer et al., 1997).

In the Cabo Ortegal Complex, early Paleozoic ages (490$480 \mathrm{Ma}$ ) were obtained by Peucat et al. (1990; U-Pb on zircons) in metabasic rocks, and interpreted as dating the high- $P$-high- $T$ metamorphism. This interpretation has been confirmed by $\mathrm{U}-\mathrm{Pb}$ dating of monazites in paragneisses and zircons in a vein formed during the partial melting that followed the high- $P$-high- $T$ event (Fernández-Suárez et al., 2002). Furthermore, U-Pb ages between 405 and 390 Ma have been obtained on zircons, monazites, titanites, and rutile (Schäfer et al., 1993; Santos Zalduegui et al., 1996; Ordóñez Casado et al., 2001; Fernández-Suárez et al., 2002), pointing to an Early Devonian metamorphic event that was followed by a subsequent retrograde amphibolite facies metamorphism at 390-380 Ma (Dallmeyer et al., 1991, 1997; Valverde Vaquero and Fernández, 1996).

Intermediate-P upper units: Fornás, Monte Castelo, Corredoiras, $O$ Pino, and Betanzos. The intermediate- $P$ upper 
units occupy the higher structural positions in the nappe pile. They include a thick sequence of terrigenous metasediments, and bodies of amphibolites, gabbros, and orthogneisses. Metamorphism ranges from the granulite facies in the lower parts to the greenschist facies above. Changes in metamorphic grade are abrupt and occur in detachments, tentatively viewed as extensional due to their subtractive character (Díaz García, 1990, 2000). High-grade rocks occupy the lowermost position among these units and occur as massifs of metaigneous rocks: the Fornás unit (amphibolites), the Monte Castelo unit (gabbro), and the Corredoiras unit (orthogneiss). These are separated from the overlying $\mathrm{O}$ Pino unit, which is essentially mesozonal, by subtractive detachments, and a major low-dipping fault, the Ponte Carreira detachment, separates the mesozonal schists and paragneisses from the uppermost slates and graywackes of the Betanzos unit (Plates 2 and 3; Fig. 3).

A magmatic and metamorphic event affected the intermediate- $P$ upper units during the Early Ordovician (Abati et al., 1999), thereby pointing to their polymetamorphic and polyorogenic character. The igneous rocks and a good part of the metamorphic parageneses belong to the Early Ordovician event, but the exact extent of the Variscan metamorphic imprint is not yet fully established. Crosscutting relationships suggest that a few of the extensional detachments are pre-Variscan, possibly related to the Ordovician event (Abati, 2000; González Cuadra et al., 1999), whereas others, such as the Ponte Carreira detachment and the Corredoiras detachment, are early Variscan (Fig. 3).

Fornás unit. This unit crops out in the southwest of the Ordenes Complex, and consists of heterogeneous and well-foliated amphibolites. Van Zuuren (1969) described preserved igneous textures, indicating a gabbroic origin, and granulite facies relics. The dominant amphibolite facies foliation developed subsequently, during the exhumation, in a shear zone that carried them into contact with the overlying mesozonal schists and paragneisses. This shear zone is a subtractive detachment, and was subsequently affected by recumbent folds with east vergence, repeated by a thrust and back-folded (Plate 3, section 7; Fig. 3).

Monte Castelo unit. A massive two-pyroxene gabbro crops out in the west of the complex. It has a tholeiitic character, similar in composition to modern island-arc basalts (see Andonaegui et al., this volume). Textures vary from granular to intergranular and ophitic. The presence of olivine and the common ophitic textures point to a relatively shallow emplacement. U-Pb analyses on zircons from the gabbro are concordant and overlap, giving a precise age of $499 \pm 2$ Ma (Abati et al., 1999), interpreted as the age of crystallization of the protolith (Fig. 4). Near its bottom, the gabbro is cut by granulite facies prograde shear zones, which produced a complete recrystallization of the igneous paragenesis. Monazite inclusions within biotite in a granulite facies rock of pelitic composition inside the gabbro yielded an age of $498 \pm 2 \mathrm{Ma}$ (Fig. 4), whereas rutiles in the same sample gave ages of 380-390 Ma, $100 \mathrm{~m}$.y. younger than the ages yielded by the monazites (Abati et al., 1999).
Separating the gabbro from the overlying amphibolite facies paragneisses of the $\mathrm{O}$ Pino unit, a subtractive detachment occurs, marked by narrow granitic bands 50-100 m thick (Plate 3 , section 9), and by the phyllonitization of the rocks (Abati, 2000). Kinematic criteria show a consistent top-to-the-south or southwest motion. The granites appear deformed and show abundant restites of paragneisses from the surrounding metasediments. Zircons and monazites from the granites give an age of $500 \pm 2 \mathrm{Ma}$ (Abati et al., 1999).

Corredoiras unit. Most of the unit is a coarse-grained metagranodiorite that crops out in the eastern part of the Ordenes Complex (Plates 2 and 3). U-Pb dating on zircons gave $500 \pm 2$ Ma (Abati et al., 1999), considered the age of intrusion (a similar age was obtained by Kuijper, 1980). The massif is variably gneissified, and kilometer-scale xenoliths of hornfelses and migmatites occur inside the orthogneisses. The xenoliths, hornfelsic in origin as indicated by preserved relics, were migmatized during a subsequent high-grade metamorphic event that also affected the orthogneisses. This event has been dated in two migmatite samples, by monazites included in biotite from the high-grade association, giving ages of $493 \pm 2$ and $484 \pm 2 \mathrm{Ma}$ (Abati et al., 1999). The temperature necessary for migmatization was above the closing temperature of the $\mathrm{U}-\mathrm{Pb}$ system in monazite, ensuring that the ages date the high-grade metamorphic fabric and that monazites are not contact-metamorphism relics. The Barrovian character of this high-grade metamorphism points to an Early Ordovician compressional event.

Following crustal thickening, an extensional detachment brought into contact metasediments of the garnet zone above, with the high-grade orthogneisses below (Figs. 3 and 5). Subsequently, both the orthogneisses and the detachment were folded and overprinted by ductile thrusts developed under a new Barrovian metamorphic gradient, in staurolite-zone conditions (González Cuadra et al., 1999). These thrusts were overprinted by the mylonitic zone associated with the Corredoiras detachment (see Plate 3, section 1).

$O$ Pino unit. A thick pile of mesozonal monotonous schists and paragneisses overlies the high-grade metaigneous massifs. This is a classical Barrovian pile, with metamorphic zones ranging from the sillimanite below, to the almandine above (Castiñeiras et al., 2000). Monazites from semipelitic paragneisses of the sillimanite zone have yielded ages of $493 \pm 1.3$ and $496 \pm 3 \mathrm{Ma}$ (Abati et al., 1999).

The unit appears as two large lens-shaped massifs separated from the underlying higher grade units by old extensional detachments, and from the overlying low-grade unit by another extensional low-dipping fault, the Ponte Carreira detachment. This fault is probably Variscan, and is marked by a zone of phyllonitization with abundant quartz veins and kinematic criteria indicating top-to-the-north motion (Díaz García, 2000).

Betanzos unit. This unit occupies the uppermost structural position and consists of 2000-3000 m of pelites and graywackes that can be separated into two formations (Díaz García, 2000). The lower formation is composed of metapelites, often car- 
bonaceous, with alternations of gray to black quartzites. The upper formation has a flyschoid appearance and consists of metagraywackes and slates, with minor conglomerates. The facies and sedimentary structures indicate a turbiditic character (Matte and Capdevila, 1978; Gutiérrez Alonso et al., 2000). Most of the sandstones are feldspathic graywackes with a framework of quartz and fresh plagioclase. Rock fragments with vitric and microgranular textures are common in the polymictic conglomerates and coarse-grained graywackes, together with slates, cherts, and clasts of bipyramidal quartz. The abundance of volcanic components, when considered together with the chemistry of the Monte Castelo gabbro, suggests a volcanic arc environment for the intermediate- $P$ upper units. However, the lack of truly volcanic rocks points to a dissected magmatic arc, the Betanzos unit representing a forearc or backarc basin fill.

The sediments were affected by greenschist facies metamorphism and by early recumbent and late steep folds (Matte and Capdevila, 1978). Two whole-rock ${ }^{40} \mathrm{Ar} /{ }^{39} \mathrm{Ar}$ analyses carried out in the greenschist facies metapelites yielded $333.3 \pm 0.3$ and 294.7 \pm 0.2 Ma (Dallmeyer et al., 1997), indicating that thermal activity took place during most of Carboniferous time.

\section{COMPARING THE AUTOCHTHON AND ALLOCHTHON STRUCTURAL HISTORIES}

The structural evolution of the autochthon (and the lower allochthon or schistose domain, see Fig. 2) is relatively simple; structures correspond to three main deformation events that developed during convergence following collision (Pérez-Estaún et al., 1991).

The first event $\left(D_{1}\right)$ produced large-scale recumbent folds with east vergence and overturned limbs attaining $30 \mathrm{~km}$ in length (Matte, 1968; Bastida et al., 1986). These folds have an axial planar cleavage, which is the oldest penetrative fabric recognized. The recumbent folds were transported toward the east in the hanging wall of second-phase $\left(\mathrm{D}_{2}\right)$ ductile shear zones and thrusts (Marcos, 1973; Bastida et al., 1986). These ductile shear zones are associated with a second cleavage development and recumbent folding, but these folds are smaller, rarely exceeding a few meters. Other structures in the authochthon are extensional detachments, synkinematic to late kinematic with the thrusting phase, and late steep folds and transcurrent shear zones, usually ascribed to the third deformation phase $\left(\mathrm{D}_{3}\right)$.

The allochthonous complexes are more complicated; for example, the basal units were probably part of the Gondwana margin like the autochthon. However, the large recumbent anticline identified in the Lalín unit (Plate 3, section 5) folds a foliation $\left(\mathrm{S}_{2}\right)$ that overprints an earlier tectonic foliation $\left(\mathrm{S}_{1}\right)$, which is preserved as microinclusions in porphyroblasts. This recumbent fold may be comparable to $\mathrm{D}_{1}$ structures in the autochthon, but for the basal units, is at least a third-phase structure. The Lalín-Forcarei thrust may be considered equivalent to the second-phase thrusts of the autochthon $\left(\mathrm{D}_{2}\right)$, but here the foliation developed along its shear zone is at least $\mathrm{S}_{3}$.
There are also differences in the ophiolites. The structural history of the Vila de Cruces unit might, in principle, be compared to that of the autochthon: a first phase of recumbent folding followed by a second one with smaller structures, and by a thrust system. However, the abundance of serpentinite lenses intercalated between metapelites and greenstones and involved in the first recumbent folding suggests an early imbrication, prior to the recumbent folding.

Two different thrust systems have been identified in the ophiolitic Careón unit. The older system was initiated in relatively high metamorphic conditions $\left(625-680{ }^{\circ} \mathrm{C}\right.$ and $11-12$ kbar) and was responsible for the stacking of the three main thrust sheets identified. Top-to-the-east kinematics characterize this mantle-rooted thrust system, which represents the imbrication of oceanic slivers in the early Variscan accretionary wedge (Díaz García et al., 1999a). Subsequently, retrogressive greenschist facies metamorphism concentrated close to the thrust surfaces indicates continued motion of the thrusts sheets into higher structural levels. This former thrust system was overprinted by a younger one, which was entirely developed in low-grade conditions, and shows top-to-the-southeast motion. The later system affected mostly the upper and lower boundaries of the Careón unit, and is related to the emplacement of the ophiolitic and upper units into their present position.

The major differences may be expected in the upper units, because of their polyorogenic evolution. Structural analysis and radiometric ages permit the definition of two complete cycles of burial followed by exhumation. Ordovician compression is deduced from the metamorphic parageneses and isotopic dating, but no unequivocal associated structures (other than relic foliations and granulite facies prograde shear zones in the Monte Castelo gabbro) have been identified. Conversely, extensional structures associated with the pre-Variscan exhumation have been found. The detachments that separate the massifs of Fornás, Corredoiras, and Monte Castelo from the O Pino unit (Plate 3; Fig. 3) are examples of extensional structures that seem to belong to this category. The first two structures were overprinted by recumbent folds and thrusts with typical Variscan attitude and kinematics (González Cuadra et al., 1999). The third example has granitoids of Early Ordovician age marking the detachment (Abati, 2000).

\section{TECTONIC INTERPRETATION}

\section{Pre-Variscan tectogenesis}

Little is known about the Early Ordovician event, except that it involved shortening and crustal thickening (intermediateto high- $P$ metamorphism) and was related to coeval magmatism of arc affinity. Both characteristics, together with the volcanic components so abundant in the low-grade Betanzos unit, imply an active continental margin or island-arc environment (Abati et al., 1999; Abati, 2000; Díaz García, 2000; Andonaegui et al., this volume). 
The Early Ordovician plutonic and metamorphic ages of the upper units correlate with the Penobscottian event in the Appalachians and contemporaneous events (Finnmarkian, Grampian) in other parts of the Caledonian belt. However, these early Taconian episodes are commonly ascribed to convergence related to the closure of the Iapetus ocean, and occurred along the northern margin of Avalon (Hossack and Cooper, 1986; Soper, 1988; Hutton, 1989; Keppie, 1989; Neuman and Max, 1989; Ohta et al., 1989; Cawood et al., 1995; Hibbard and Samson, 1995; Winchester and Van Staal, 1995). Given the position of Iberia close to the junction of the Appalachians, the Caledonides and the Variscides (Fig. 1), it could be possible that a piece of lithosphere detached from the early Taconian belt was thrust on top of the Iberian autochthon. The large displacements associated with the thrust systems described in the following could, in principle, support such an interpretation.

However, Early Ordovician metamorphic ages also have been found in areas of the Variscan belt far from the junction of the three orogenic belts, such as the Alps (Von Raumer and Neubauer, 1993), particularly in the Tauern Window (Frisch and Neubauer, 1989), the Black Forest, the Bohemian Massif, and the Holy Cross Mountains (Franke, 1989), that support a relationship with peri-Gondwanan activity. Convergence inside the Rheic ocean may explain the Early Ordovician metamorphism and magmatism without the intervention of a volcanic arc extraneous to the Gondwana realm.

\section{Early Variscan structures: Building the orogenic wedge}

The Variscan history can be better established, thanks to the wealth of structural and petrologic data available and to the isotopic ages of the main fabrics. The Early Devonian protolith age obtained in the Careón unit provides evidence for oceanic crust generation and delimits the upper limit for the closure of the intervening ocean and the lower limit for the beginning of intracontinental deformation.

Diachronism of deformation. The ages of the retrogressive amphibolite facies foliation in the high- $P$-high- $T$ upper units (405-380 Ma) mark the onset of Variscan deformation in the allochthonous units. They are followed by those on the upper ophiolites (390-375 Ma), which are prograde, and by the greenschist facies foliation in the lower ophiolites (370-365 Ma) and the posteclogitic, exhumation foliation in the basal units (375-365 Ma). These age intervals (Fig. 7, A and B) show younging of the main Variscan foliations from the top to the bottom of the nappe pile. This younging continued: the age of the main foliation in the autochthon, 360-335 Ma for the first cleavage, is associated with $\mathrm{D}_{1}$ recumbent folding (Dallmeyer at al., 1997). The oldest age corresponds to the more internal areas and to the units occupying a relatively higher structural position within the autochthon, in the vicinity of the allochthonous complexes (Fig. 7C). The youngest age was obtained at the contact with the foreland thrust belt, which was structurally lower in the orogenic wedge (see cross section in Fig. 2).
The diachronism shown by the structures in both the allochthon and the autochthon, with ages older in the more internal and structurally higher units, can be extrapolated farther to the west. Because northwestern Iberia was close to the Grand Banks of Newfoundland at the end of the Variscan cycle (Lefort, 1989), the extrapolation may be prolonged into Atlantic Canada. The first cleavage in the Meguma terrane, the outermost accreted terrane of Canadian Appalachians, is dated as 415-390 Ma (Dallmeyer and Keppie, 1987). The accretion of Avalon to Laurentia occurred during the Late Ordovician to Early Silurian, along the late Taconian and Salinian deformations, between 460 and 430 Ma (Cawood et al., 1995; Murphy et al., 1995). Surface geology and deep seismic reflection profiles show that Avalon was underthrust westward beneath the Laurentian plate, perhaps as much as 200 km (Hatcher, 1989; Keen et al., 1989; Quinlan et al., 1992).

Accretionary sequence. The deformation in the Iberian allochthonous complexes and, in particular, the subduction of some of their units, probably reflects the continued understacking of continental, arc, and oceanic fragments to the west (Fig. 7A). Underthrusting followed the accretion of Avalon to Laurentia, and resulted from the convergence between Laurentia and Gondwana (Martínez Catalán et al., 1997, 1999). The 405-390 Ma ages would reflect the underthrusting of the upper units. These units underwent decompression during their emplacement onto the ophiolitic units. Synchronous amphibolite facies metamorphism, dated as 390-380 Ma, was retrogressive in the high- $P$-high- $T$ upper units, and prograde in the underlying ophiolites, where it reflects the westward understacking of the oceanic lithosphere related to the closure of the intervening ocean (Díaz García et al., 1999a). In turn, this closure was immediately followed by the subduction of the outer continental edge of Gondwana (Fig. 7B). The $P-T$ conditions reached by the basal units during this event vary according to the position inside the crustal subduction complex. Although affected by subsequent recumbent folding, a prefold reconstruction indicates that higher pressure assemblages occurred to the west: therefore, a westward polarity is deduced for the subduction.

After having registered the peak pressures, the metamorphic evolution in most of the units accreted to the orogenic wedge was governed by a strong decompression. Normally, the development of the regional foliation was synkinematic with decompression, which was attained via thrusting and unroofing of the thrust sheets. Thrusts associated with the initial Variscan accretion are probably preserved, but their identification is by no means unequivocal. The most probable thrusts of this type have been identified in the Careón (Díaz García et al., 1999a) and Corredoiras units (Fig. 3). Removal of the overburden was partially accomplished by extensional detachments, such as the Corredoiras detachment and the Ponte Carreira detachment (Plate 3; Fig. 3), with roughly northsouth motion, implying crustal flow normal to the direction of shortening. 


\section{Emplacement of the allochthonous units: Thrusts and detachments}

The role of thrusting in the emplacement of the allochthonous complexes of northwestern Spain was put forward by Ries and Shackleton (1971) and Bayer and Matte (1979). In the Ordenes Complex, contributions were made by Hilgen (1971), Martínez Catalán et al. (1984), and Díaz García (1990).

Other than the early Variscan thrusts associated with the accretion of the allochthonous units to form the initial orogenic wedge, the more important thrusts identified so far are the LalínForcarei thrust, separating the basal units from the lower allochthon, and the thrust system that carried the upper units on top of the ophiolites. These thrusts were cut by a low-dipping normal fault with top-to-the-northwest motion, the Pico Sacro detachment. This fault overprints all of the thrusts and many granite intrusions, and was affected by late upright folding. Furthermore, it was cut by steeply dipping faults with normal and strike-slip components in the east and west parts of the complex (Plates 2 and 3; Fig. 3).

Thrusting of the basal units. The Lalín-Forcarei thrust postdates the high- $P$ event in the basal units: therefore, it must be younger than $365 \mathrm{Ma}$ (Santos Zalduegui et al., 1995). Thrusting was preceded by the development of a huge recumbent anticline, and it seems probable that both the fold and the LalínForcarei thrust were developed in a wide regional shear zone responsible for the exhumation of the basal units.

The thrust sheet was overlain by the Campo Marzo unit, a piece of hot, probably subophiolitic mantle, that induced a heating from above and gave rise to an inverted metamorphic gradient in the basal units during decompression (Fig. 5). Its lower limit is a slightly folded low-dipping fault (Campo Marco detachment) with kinematic criteria indicating top-to-the-south motion. In the Santiago unit, also heated by an overlying source, kinematic criteria in the foliation coeval with the inverted metamorphism also supply a top-to-the-south sense of shear. This means motion normal to the direction of shortening, and in the northwestern Iberian Massif, this is usually associated with synorogenic extension (Escuder Viruete et al., 1994; Díez Balda et al., 1995; Díaz García et al., 1999b).

The emplacement of the hot slab followed the recumbent folding of the basal units, and was contemporaneous with the development of a new regional foliation and of migmatization in the upper parts of the Forcarei, Lalín, and Santiago units. The new foliation $\left(\mathrm{S}_{3}\right)$ is roughly synchronous with the emplacement of the Lalín and Forcarei units (Martínez Catalán et al., 1996), although the isograds of the inverted metamorphism reached and overprinted the Lalín-Forcarei thrust once motion had ceased on it, due to the low velocity of heat transfer in rocks.

If the migmatization of the Agualada unit was caused by the emplacement of the same mantle unit preserved in Campo Marzo, the 346 Ma age obtained by Abati and Dunning (2002) in Agualada can be taken as a reference for the age of the LalínForcarei thrust. This age is consistent with the regional cleavage developed in the underlying lower allochthon during the emplacement of the overlying basal units, where a cooling age of $340 \pm 0.9$ Ma was obtained by Dallmeyer et al. $\left(1997 ;{ }^{40} \mathrm{Ar} /{ }^{39} \mathrm{Ar}\right.$ whole-rock analysis on phyllite). Furthermore, Dallmeyer et al. (1997) dated the second-phase foliation in the autochthon, related to thrust faults, as between $345 \mathrm{Ma}$, in the internal areas, and $320 \mathrm{Ma}$, at the limit with the foreland thrust belt (Fig. 7C).

Taking into account the uncertainties on the age of the high$P$ event and of the Lalín-Forcarei thrust, this important thrust, dated as between 365 and $340 \mathrm{Ma}$, seems to follow a complex but essentially normal sequence of burying and exhumation. Subsequently, thrusting propagated into the authochthon, prograding toward the external zones where the thrusts and associated ductile shear zones overprinted recumbent folds but no previous thrust faults.

Thrusting of the upper and ophiolitic units. The emplacement of the upper units and ophiolites took place along a system of out-of-sequence thrusts developed under low- $T$ conditions.

One of the more important thrusts of this system separates the upper units from the Bazar, Careón, and Vila de Cruces units. In the southeast of the Ordenes Complex, it carried the high$P$-high- $T$ upper units of Sobrado, Melide, and Belmil, together with the overlying Corredoiras unit, over the ophiolites (Plate 3, section 2; Fig. 3). Furthermore, the fault cut across two different thrust sheets of the previously stacked Careón unit. The associated mylonites and ultramylonites show a stretching northwestsoutheast lineation and top-to-the-southeast sense of motion.

The Sobrado and Belmil units crop out in northeast-southwest-striking antiforms that seem to be related to the thrusting. The first unit is a duplex, of antiformal stack type, where the imbricates are three high- $P$-high- $T$ slices reflecting $P$ - $T$ conditions progressively higher downward in the stack. This may be explained by the thrusts cutting across a granulite-eclogite slab placed onto the ophiolites by an early thrust, and sampling it as shown in Figure 6A. The Belmil unit is the uppermost horse of an antiformal stack that also involves horses of the Careón and Vila de Cruces units (Plate 3; Figs. 3 and 6B).

In both cases, the mylonites of the Corredoiras detachment surround the high- $P$-high- $T$ rocks, which crop out as tectonic windows. Mylonitization occurred under amphibolite facies conditions and has been dated as ca. 375 Ma by Dallmeyer et al. (1997). The Corredoiras detachment clearly predates the out-ofsequence thrusts, which proceeded under greenschist facies conditions. Other minor slices of high- $P$-high- $T$ mafic rocks occur in the area (Plates 2 and 3) and are viewed as small isolated horses related to this major thrust system.

Southwest of Belmil, a thrust separates the intermediate- $P$ upper units from the lower ophiolites (Vila de Cruces unit), although the intervening Careón unit is not totally absent and crops out in two isolated horses (Plates 2 and 3, section 4). In the hanging wall of the main thrust, dragging of the Corredoiras orthogneiss during eastward motion left a tail of orthogneiss more than $15 \mathrm{~km}$ long, and a dismembered orthogneiss horse on top of a high- $P$-high- $T$ horse to the south of Touro. In the foot- 
wall, duplexes formed in the Vila de Cruces unit. They include the hinterland dipping and antiformal stack types, as well as a few foreland-dipping horses of Vila de Cruces and Careón units in the Belmil duplex.

In the west of the complex, the intermediate- $P$ upper units were thrust over the ophiolitic Bazar unit, and this over the basal Santiago unit (Plate 3, section 9; Fig. 3). Northwest of Carballo, an imbricate thrust carried an ophiolitic horse on top of the O Pino unit (Plate 2). A comparable tectonic mixing is seen in the Belmil duplex, where a horse of high- $P$-high- $T$ gneisses is intercalated between imbricates of the Careón unit (Plate 3, section 3 ).

Although thrust faults are usually additive, the out-of-sequence-thrusts are characterized by subtractions such as the disappearance of the Careón unit southwest of Belmil, and of the high- $P$-high- $T$ units along most of the contact between the intermediate- $P$ upper units and the ophiolites. Other subtractions, such as the lack of Vila de Cruces unit to the west and of the basal units to the east, may be partially due to the late extensional Pico Sacro detachment, but the thrust system also played a role. There is no doubt that the faults are of the thrust type, because of the presence of contractional imbricates. The disappearance of units may be attributed to superposition of two thrust generations. This can be seen in the Careón unit, where young, low-temperature thrusts cut an older imbricate stack. Consequently, an out-of-sequence character is deduced for this thrust system.

The out-of-sequence thrusts include duplexes for which displacement equals (antiformal stacks) or exceeds (forelanddipping duplexes) fault spacing (Mitra and Boyer, 1986), and the isolated horses involve still larger displacements. Figure 6 shows the evolution of the out-of-sequence thrusts in the southeast of the Ordenes Complex. A partial restoration has been attempted in the Vila de Cruces unit, obtaining more than $50 \mathrm{~km}$ of shortening only inside this unit (Fig. 6C).

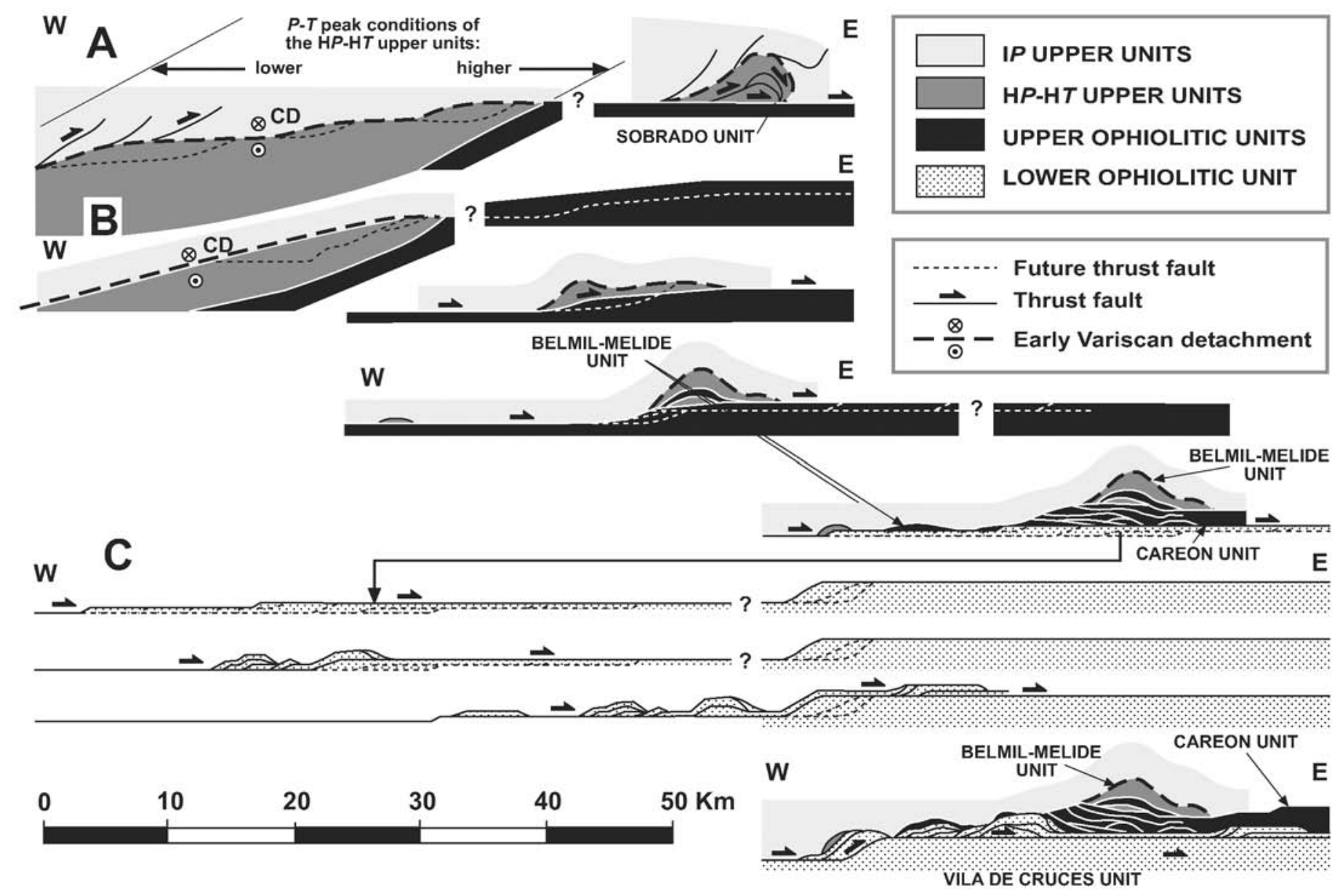

Figure 6. Development of structures associated with out-of-sequence thrusts. A: Development of Sobrado antiformal stack formed by three horses with metamorphic grade increasing downward. B: Development of antiformal stack involving Belmil unit, and horses of Careón and Vila de Cruces units. C: Partial restoration and possible sequence of thrusting of Vila de Cruces imbricates, showing more than $50 \mathrm{~km}$ of shortening. IP, intermediate pressure; $\mathrm{H} P$ - $\mathrm{H} T$, high-pressure-high temperature. 
The Corredoiras detachment had developed long before these late thrusts, overprinting early Variscan imbricate structures cutting across the Corredoiras unit (Plate 3, section 1; Figs. 3 and 6A). However, the Corredoiras detachment was reactivated during the out-of-sequence thrusting. Its mylonites, developed under amphibolite facies conditions and with top-tothe-north or northeast sense of shear, were involved in top-to-the-southeast thrusting and mylonitized in greenschist facies conditions to the east of Sobrado and Belmil (Plate 3). In a late pulse, brittle reverse faults dissected the duplexes (Plate 3, sections 1 and 3; Fig. 3).

The out-of-sequence-thrusts cut the Agualada unit, so that they are younger than $346 \mathrm{Ma}$, the age of the migmatization in this unit (Abati and Dunning, 2002). They are also younger than the Lalín-Forcarei thrust, structurally beneath and overprinted by amphibolite facies conditions, a metamorphism that never affected the out-of-sequence thrusts. However, they must be older than the late extensional Pico Sacro detachment, bracketed between $323 \pm 11$ and $314 \pm 6 \mathrm{Ma}$ (see following).

An age constraint is given by a ${ }^{40} \mathrm{Ar} /{ }^{39} \mathrm{Ar}$ cooling age of 325 $\mathrm{Ma}$ in a greenschist facies ultramylonitic gneiss of the upper slice of the Sobrado unit (Dallmeyer et al., 1997; see Fig. 4) that seems to mark a thrust contact. Dallmeyer et al. (1997) also recorded a $316 \mathrm{Ma}$ age in a phyllonite at the base of the Cabo Ortegal Complex. These represent cooling ages of fine-grained white micas, and probably mark different episodes of out-of-sequence thrusting, because the emplacement of the upper and ophiolitic units was probably a protracted event. In any case, the out-of-sequence thrusts are between 40 and 70 m.y. younger than the amphibolite and greenschist facies foliations dated in the upper and ophiolitic units, and interpreted as related to the building of the orogenic wedge.

Figure 7D depicts the interpretation given to the out-of-sequence thrusts. A narrow band of low-dipping thrust faults cuts and displaces former boundaries between units stacked previously in a more or less sequential way. Thrusting directed to the southeast or east-southeast would have sampled the high$P$-high- $T$ upper units and the ophiolites, which appear sandwiched between the intermediate- $P$ upper units and the basal units. According to this interpretation, dismembering of the units, particularly of the high- $P$-high- $T$ upper units and of the ophiolites, should mostly be attributed to the out-of-sequence thrusts. The low inclination of the out-of-sequence thrusts accounts for the fact that they produced little exhumation of the units involved, which were relatively exhumed and cold.

Pico Sacro detachment system. The Pico Sacro detachment is the last and more continuous extensional detachment in Ordenes. Initially described by Van Zuuren (1969), it can be followed from the southeast near Palas de Rei, to Santiago in the southwest, and continues northward along the contact of the Ordenes Complex nearly up to the coast (Plates 2 and 3; Fig. 3). It shows a subtractive character, indicated by the omission of units and by a jump in the grade of the late significant metamorphism. South of Vila de Cruces, the fault cuts the basal units: the nor- mal limb of the recumbent fold making the northern part of the Lalín unit occurs in the footwall of the Pico Sacro detachment and reappears, displaced to the west, as the Santiago unit at its hanging wall.

The detachment shows a consistent top-to-the-northwest motion. Along most of its length, there is a metamorphic contrast between the high-grade schists, migmatites, and granites of its footwall and the less metamorphic, often low-grade rocks of its hanging wall. Some granites were late enough to pierce the detachment (Plate 3). On petrological grounds, the vertical component of the fault is estimated as $\sim 5 \mathrm{~km}$ (Marquínez García, 1984), and the horizontal component cannot exceed $20 \mathrm{~km}$, because of the initial continuity between the orthogneisses in the north of Lalín and in the south of Santiago (Martínez Catalán et al., 1996).

Several associated normal faults occur in the hanging wall of the Pico Sacro detachment, in the south and east. The most important defines the western limit of the Corredoiras unit. This is a listric fault, downthrown to the west, that joins the Pico Sacro detachment to the southwest of Vila de Cruces, in an area characterized by a network of conjugated normal faults (Plates 2 and 3; Fig. 3). However, to the west of this network, several contractional structures seem to partially compensate the extension associated with the Pico Sacro detachment to the east. These structures include back folding of the Fornás unit and reverse faulting with top-to-the-west motion affecting the Monte Castelo unit (Díaz García, 1990). These structures seem to have followed local reactivation of an important out-of-sequence thrust (Plate 3; Fig. 3).

The Pico Sacro detachment cuts the granodiorites of $\mathrm{Ne}$ greira in the west, and Palas de Rei in the east (Plates 2 and 3), dated as $350 \pm 11$ and $323 \pm 11 \mathrm{Ma}$, respectively (Bellido et al., 1992). It also overprints a set of late, roughly northwest-southeast upright folds: the Lalín and Forcarei synforms and the intervening antiform (Plates 2 and 3; Fig. 3). However, it is in turn folded by a younger set of upright folds, striking north-south to northeast-southwest (Plate 3; Fig. 3), that are responsible for the present synformal structure of the Ordenes Complex (excluding the Lalín and Forcarei units). These folds are associated with transcurrent shear zones, of which the sinistral Palas de Rei shear zone in the east is the most important (Plate 2). The age of these late upright folds was estimated as $314 \pm 6$ Ma by Capdevila and Vialette (1970; corrected by Ries, 1979). This age, together with that of the Palas de Rei granodiorite, brackets the Pico Sacro detachment system between $323 \pm 11$ and $314 \pm 6 \mathrm{Ma}$.

High-angle faults developed finally at the east and west margins of the Ordenes Complex. One of these faults, essentially normal, separates the complex from the Variscan granitoids west of Palas de Rei. Another occurs west of the Forcarei synform, separating the granites from the metasediments. This fault has a sinistral strike-slip component and a dip-slip movement, and can be followed discontinuously to the north up to the eastern limit of the Monte Castelo unit. The dip-slip movement, downthrown to the east, is probably the cause of the flexure un- 

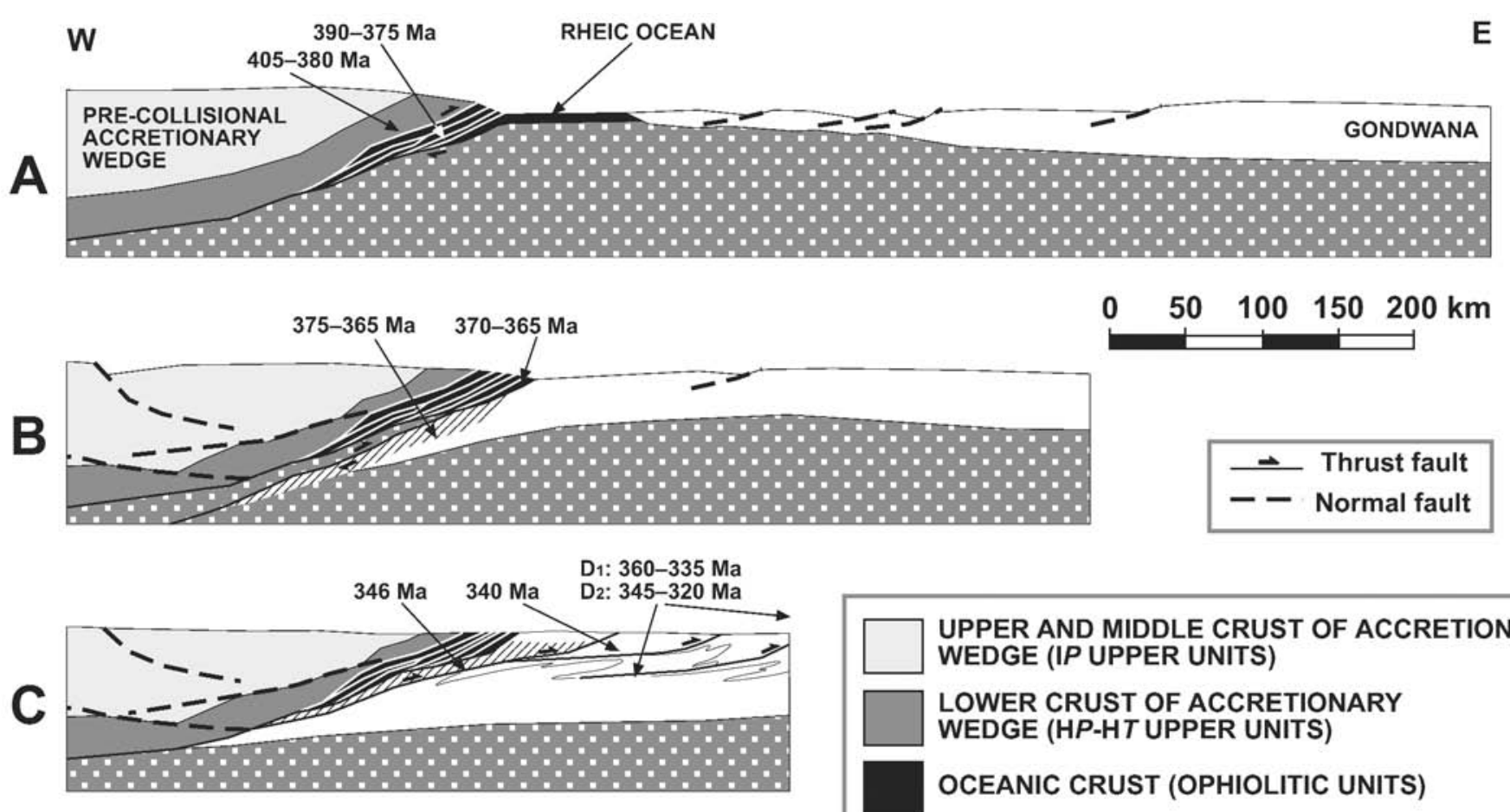

UPPER AND MIDDLE CRUST OF ACCRETIONARY WEDGE (IP UPPER UNITS)
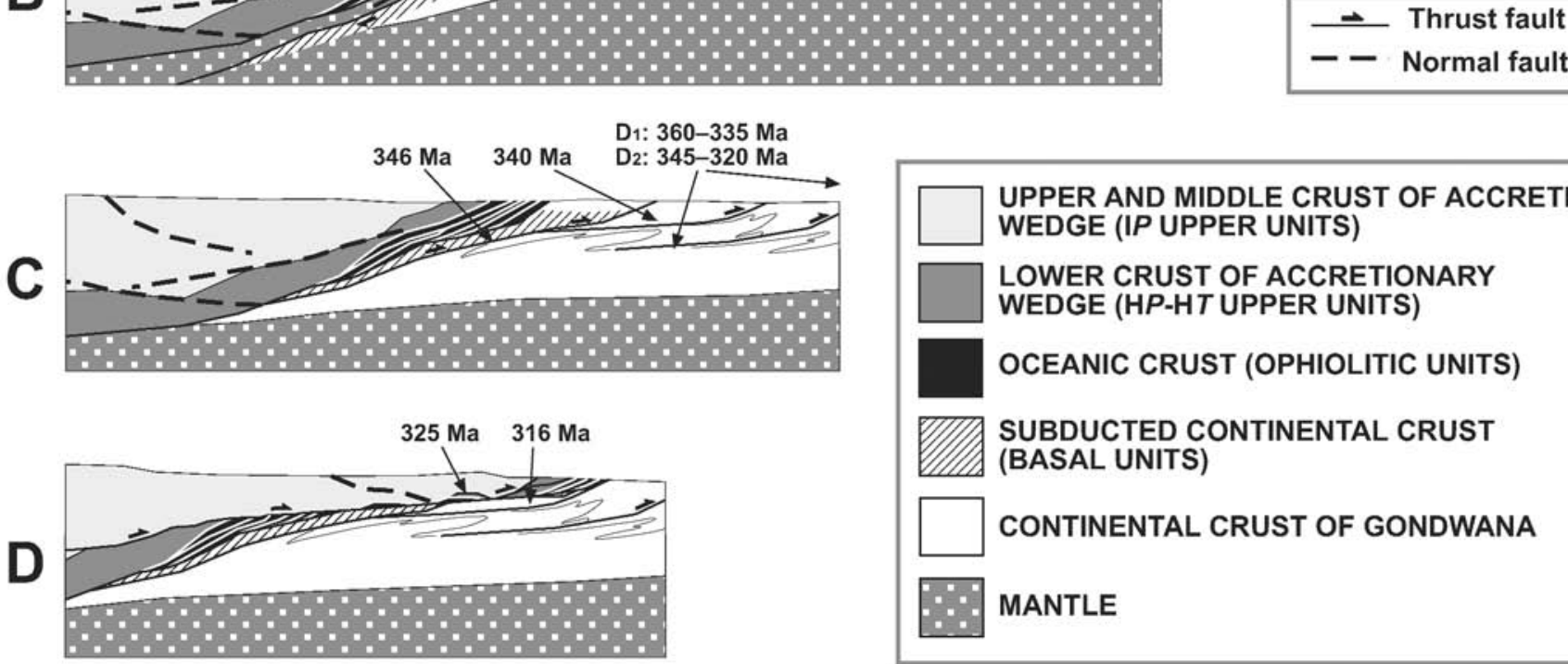

LOWER CRUST OF ACCRETIONARY WEDGE (HP-HT UPPER UNITS)

OCEANIC CRUST (OPHIOLITIC UNITS)

SUBDUCTED CONTINENTAL CRUST (BASAL UNITS)

CONTINENTAL CRUST OF GONDWANA

MANTLE

Figure 7. Proposed stages in emplacement of allochthonous complexes of northwestern Iberia. A: Building of accretionary wedge by progressive terrane accretion to Laurentia during Devonian. B: Subduction of outer edge of continental margin of Gondwana. C: Thrusting of basal units and lower allochthon, and thickening of Gondwana continental crust. D: Development of out-of-sequence thrusts and emplacement of upper and ophiolitic units to their present position. U-Pb and ${ }^{40} \mathrm{Ar} /{ }^{39} \mathrm{Ar}$ ages of regional fabrics after Dallmeyer et al. (1991, 1997), Schäfer et al. (1993), Ordóñez Casado et al. (2001), Santos Zalduegui et al. (1996), Valverde Vaquero and Fernández (1996), and Fernández-Suárez et al. (2002). IP, intermediate pressure; $\mathrm{H} P$-HT, high-pressure-high temperature.

dergone by the overall subhorizontal structure in the steeply dipping corridor north of Santiago (Plate 3, section 8; Fig. 3).

\section{IMPLICATIONS FOR THE \\ VARISCAN-APPALACHIAN GEODYNAMICS}

The Early Ordovician magmatic and tectonometamorphic event identified in the upper units reflects convergence in the peri-Gondwanan realm. This interpretation contrasts with the well-established fact that the Iberian autochthon was undergoing extension during the Early Ordovician (Ribeiro and Floor, 1987; Liñán and Quesada, 1990), related to peri-Gondwanan terrane dispersion (Fortey and Cocks, 1988; Soper, 1988). The apparent contradiction is solved by Von Raumer et al. (2001) and Stampfli et al. (this volume) by relating the drifting of European
Variscan terranes to slab rollback of the ProtoTethys and Rheic oceanic lithospheres. Therefore, a short-lived orogenic event parallels, in this peri-Gondwanan terrane, the early Taconic convergence related to the closure of the Iapetus ocean in the Laurentian margin.

The upper units also contain the first evidences of Variscan convergence. The 405-390 Ma metamorphic ages reflect their accretion to an orogenic wedge that was being constructed on the Laurentian side. This time interval was preceded by deformation in Atlantic Canada (Dallmeyer and Keppie, 1987; Cawood et al., 1995; Murphy et al., 1995), and followed by accretion of oceanic lithosphere (ophiolitic units, Fig. 7A) and by limited subduction of the basal units. No evidence exists for separation of the Iberian autochthon from Gondwana during the Paleozoic. Therefore, the basal units must represent the outer edge 
of the Gondwana continental margin (Fig. 7B), and the end of subduction, dated as 374-365 Ma (Van Calsteren et al., 1979; Santos Zalduegui et al., 1995), marks the onset of deformation of the autochthonous cover and basement of Gondwana (Fig. 7C), which took place during the Early Carboniferous.

Accretion of the Iberian allochthonous units was contemporaneous with the Acadian orogeny in the Appalachians that occurred from the end of Silurian to the end of Devonian (Hatcher, 1989; Osberg et al., 1989). Our data indicate that seafloor spreading was still active 395 m.y. ago in the Rheic oceanic realm (Díaz García et al., 1999a), but Gondwana-Laurentia convergence caused final oceanic closure during the Late Devonian. Continent-continent collision was accomplished during the Acadian orogeny, between Iberia and the northern Appalachians. However, convergence did not cease. The lack of significant early Carboniferous deformation in the Appalachians was compensated for by shortening and thickening on the Iberian autochthon, which, together with the rest of the European Variscides, registered the main orogenic event during the early Carboniferous.

During the late Carboniferous, a system of low-dipping thrusts cut and displaced the units, stacked previously in a more or less sequential way (Fig. 7D). A large translation toward the foreland seems associated with this out-of-sequence thrust system, which could reflect a major geotectonic event. Timing of the out-of-sequence thrusts, loosely defined as between 325 and $315 \mathrm{Ma}$, coincides with the early Alleghanian orogeny (Hatcher, 1989, 2001), which initiated continent-continent collision in the central and southern Appalachians (Hatcher, this volume). A change in the relative motion of Laurentia and Gondwana has been suggested for the Alleghanian orogeny, even though there is not agreement on the sense of rotation of Gondwana relative to Laurentia (counterclockwise, Gates et al., 1986; clockwise, Hatcher, this volume). The change of thrust transport direction from east-west (building of the accretionary wedge and in-sequence thrusts) to northwest-southeast (out-of-sequence thrusts) would rather support a counterclockwise rotation of Iberia, which did not necessarily remain passively attached to Gondwana.

\section{CONCLUSION}

The structural evolution of the Iberian allochthonous complexes is being progressively unveiled. From what we currently know, the polyorogenic character of the upper units, deduced from isotopic data, is becoming evident. The pre-Variscan structural evolution is poorly characterized, but several macrostructures in the upper units seem to be pre-Variscan. These include granulite and eclogite facies shear zones and extensional detachments.

Conversely, our understanding of the Variscan evolution is far greater. The tectonothermal evolution and isotopic ages of the regional foliations in the different allochthonous units suggest a history of subduction and progressive accretion of lithospheric pieces to an orogenic wedge, in a context of convergence between Gondwana and Laurentia (Martínez Catalán et al., 1997, 1999). The continuous understacking of continental and oceanic fragments toward the west began with the upper units, or with more internal units not represented in the northwestern Iberian complexes (Fig. 7A), and ended with the basal units (Fig. 7B). The latter represent the outermost margin of Gondwana, and their subduction marked the closure of the intervening ocean and the transition from subduction to collision. Terrane accretion took place during the Devonian and, during the Late Devonian and the early Carboniferous, the deformation progressed toward inner realms of the Gondwana margin (Fig. 7C).

New thrust generation reflects renewed shortening in the internal parts of the orogenic wedge. Associated with continued Gondwana-Laurentia convergence and possibly to a change in plate dynamics, the small thickness of the new allochthon probably resulted from the impossibility of continued continental subduction once the thick parts of the Gondwana continental crust were involved in the orogenic wedge and were additionally thickened by folding and thrusting (Fig. 7D). The buoyancy inherent to continental crust may have triggered the rupture along low-dipping thrusts to accommodate continued convergence.

Contractional structures are common in a context of convergence. Less representative, but also common, is the presence of detachments showing subtractive relationships. They are interpreted as late orogenic to postorogenic structures related to stress relaxation, but also as synorogenic structures related to gravitational equilibration on the growing orogenic wedge. Because two orogenic cycles, Early Ordovician and Variscan, have been identified in the Ordenes Complex, and the youngest of them involved several episodes of burial and exhumation, overprinting of contractional and extensional structures should be expected.

Even though each allochthonous unit and group of units underwent a particular history, many of them share the following evolutionary stages.

1. The first stage was burial accompanied by ductile deformation related to subduction and/or understacking.

2. The second stage was main exhumation, primarily associated with complex ductile shearing and involving (1) development of regional fabrics (amphibolite to greenschist facies foliation); (2) recumbent folding (large folds identified in all but the Careón and Bazar units); and (3) in-sequence, mainly ductile thrusting or complex sequence of folding and thrusting (involving more or less coeval structural thinning and tectonic denudation, and exhumation of structurally higher units coeval with accretion of lower units below).

3. The third stage was out-of-sequence thrusting with large displacements but little exhumation.

4. The fourth stage developed late extensional detachments and associated normal faults. 
5. The fifth stage was upright folding, strike-slip ductile shearing, and high-angle faulting.

\section{ACKNOWLEDGMENTS}

This study has been funded by the Spanish agencies Dirección General de Investigación Científica y Técnica and Dirección General de Enseñanza Superior e Investigación Científica, and includes results from projects PB88-0145-C02, PB91-0192C02, PB94-1396-C02, and PB97-0234-C02. We thank J. Malavieille for a few clever comments that helped to improve the graphic presentation of data and J.B. Murphy for acute suggestions and exhaustive correction of English grammar that resulted in a considerable improvement of the text.

\section{REFERENCES CITED}

Abati, J., 2000, Petrología metamórfica y geocronología de la unidad culminante del Complejo de Ordenes en la región de Carballo (Galicia, NW del Macizo Ibérico) [Ph.D. thesis]: Madrid, Spain, Universidad Complutense, $200 \mathrm{p}$.

Abati, J., and Dunning, G.R., 2002, Edad U-Pb en monacitas y rutilos de los paragneises de la Unidad de Agualada (Complejo de Ordenes, NW del Macizo Ibérico, v. 32 (in press).

Abati, J., Dunning, G.R., Arenas, R., Díaz García, F., González Cuadra, P., Martínez Catalán,J.R., and Andonaegui, P., 1999, Early Ordovician orogenic event in Galicia (NW Spain): Evidence from U-Pb ages in the uppermost unit of the Ordenes Complex: Earth and Planetary Science Letters, v. 165 , p. $213-228$.

Arenas, R., 1991, Opposite $P, T, t$ paths of Hercynian metamorphism between the upper units of the Cabo Ortegal Complex and their substratum (northwest of the Iberian Massif): Tectonophysics, v. 191, p. 347-364.

Arenas, R., and Martínez Catalán, J.R., 1993, High-pressure and high-temperature metabasites from the Sobrado Antiform (Northwest of the Iberian Massif, Spain): A petrologic and field study in a granulite-eclogite transition zone [abs.]: Terra abstracts, Abstracts Supplement no. 4, Terra Nova, v. 5, p. 1.

Arenas, R., Abati, J., Martínez Catalán, J.R., Díaz García, F., and Rubio Pascual, F.J., 1997, $P$ - $T$ evolution of eclogites from the Agualada unit (Ordenes Complex, NW Iberian Massif, Spain): Implications for crustal subduction: Lithos, v. 40, p. 221-242.

Arenas, R., Gil-Ibarguchi, J.I., González-Lodeiro, F., Klein, E., MartínezCatalán, J.R., Ortega-Girones, E. Pablo-Maciá, J.G. de, and Peinado, M., 1986, Tectonostratigraphic units in the complexes with mafic and related rocks of the NW of the Iberian Massif: Hercynica, v. 2, p. 87-110.

Arenas, R., Rubio Pascual, F.J., Díaz García, F., and Martínez Catalán, J.R., 1995, High-pressure micro-inclusions and development of an inverted metamorphic gradient in the Santiago Schists (Ordenes Complex, NW Iberian Massif, Spain): evidence of subduction and syn-collisional decompression: Journal of Metamorphic Geology, v. 13, p. 141-164.

Bard, J.P., Capdevila, R., and Matte, Ph., 1971, Structure de la chaîne hercynienne de la Meseta Ibérique: Comparaison avec les segments voisins, in Histoire structurale du Golfe de Gascogne, Editions Technip, Symposiums, Publications de l'Institute Francais du Pétrole, v. 1.4, p. 1-68.

Bastida, F., Martínez Catalán, J.R., and Pulgar, J.A., 1986, Structural, metamorphic and magmatic history of the Mondoñedo nappe (Hercynian belt, NW Spain): Journal of Structural Geology, v. 8, p. 415-430.

Bayer, R., and Matte, Ph., 1979, Is the mafic/ultramafic massif of the Cabo Ortegal (NW Spain) annape emplaced during a Variscan obduction: A new gravity interpretation: Tectonophysics, v. 57, p. T9-T18.

Bellido, F., Brandle, J.L., Lasala, M., and Reyes, J., 1992, Consideraciones petrológicas y cronológicas sobre las rocas graníticas hercínicas de Galicia: Cuadernos do Laboratorio Xeolóxico de Laxe, v. 17, p. 241-261.
Bessoles, B., 1977, Géologie de l'Afrique: Le craton ouest-africain: Mémoires du Bureau de Recherches Géologiques et Minieres 88, 402 p.

Bouchez, J.L., Lister, G.S., and Nicolas, A., 1983, Fabric asymmetry and shear sense in movement zones: Geologische Rundschau, v. 72, p. 401-419.

Caby, R., 1989, Precambrian terranes of Benin-Nigeria and northeast Brazil and the Late Proterozoic south Atlantic fit, in Dallmeyer, R.D., ed., Terranes in the Circum-Atlantic Paleozoic Orogens: Boulder, Colorado, Geological Society of America Special Paper 230, p. 145-158.

Capdevila, R., and Vialette, Y., 1970, Estimation radiométrique de l'âge de la deuxième phase tectonique hercynienne en Galice Moyenne (Nord-Ouest de l'Espagne): Comptes Rendus de l'Académie des Sciences, Paris, v. 270, p. $2527-2530$.

Castiñeiras, P., Arenas, R., Martínez Catalán, J.R., and González del Tánago, J., 2000, Mineral assemblages and $P-T$ constraints in Ky-St-Grt schists from the Arinteiro antiform (Ordenes Complex, NW Iberian Massif): VariscanAppalachian dynamics: the building of the Upper Paleozoic basement, Basement Tectonics 15: A Coruña, Spain, Program and Abstracts, p. 81-84.

Cawood, P.A., Van Gool, J.A.M., and Dunning, G.R., 1995, Collisional tectonics along the Laurentian margin of the Newfoundland Appalachians, in Hibbard, J.P., Van Staal, C.R., and Cawood, P.A., eds., Current perspectives in the Appalachian-Caledonian Orogen: Geological Association of Canada Special Paper 41, p. 283-301.

Dallmeyer, R.D., and Gil Ibarguchi, J.I., 1990, Age of amphibolitic metamorphism in the ophiolitic unit of the Morais allochthon (Portugal): Implications for early Hercynian orogenesis in the Iberian Massif: Journal of the Geological Society of London, v. 147, p. 873-878.

Dallmeyer, R.D., and Keppie, J.D., 1987, Polyphase late Paleozoic tectonothermal evolution of the southwestern Meguma Terrane, Nova Scotia: Evidence from ${ }^{40} \mathrm{Ar} /{ }^{39} \mathrm{Ar}$ mineral ages: Canadian Journal of Earth Sciences, v. 24 , p. $1242-1254$.

Dallmeyer, R.D., Ribeiro, A., and Marques, F., 1991, Polyphase Variscan emplacement of exotic terranes (Morais and Bragança Massifs) onto Iberian successions: Evidence from ${ }^{40} \mathrm{Ar} /{ }^{39} \mathrm{Ar}$ mineral ages: Lithos, v. 27, p. 133-144.

Dallmeyer, R.D., Martínez Catalán, J.R., Arenas, R., Gil Ibarguchi, J.I., Gutiérrez Alonso, G., Farias, P., Aller, J., and Bastida, F., 1997, Diachronous Variscan tectonothermal activity in the NW Iberian Massif: Evidence from ${ }^{40} \mathrm{Ar} /{ }^{39} \mathrm{Ar}$ dating of regional fabrics: Tectonophysics, v. 277, p. 307-337.

Díaz García, F., 1990, La geología del sector occidental del Complejo de Ordenes (Cordillera Hercínica, NW de España): Coruña, Spain, Laboratorio Xeolóxico de Laxe, Nova Terra, v. 3, 230 p.

Díaz García, F., 1993, Análisis comparativo de la foliación regional y estructuras asociadas en el Dominio de Santiago y su autóctono relativo (Galicia, NW de España): Revista de la Sociedad Geológica de España, v. 6, p. $105-114$.

Díaz García, F., 2000, Lithostratigraphy and structure of the A Coruña unit. Uppermost units of the Variscan Belt, NW Spain: Variscan-Appalachian dynamics: the building of the Upper Paleozoic basement, Basement Tectonics 15: A Coruña, Spain, Program and Abstracts, p. 92-94.

Díaz García, F., Arenas, R., Martínez Catalán, J.R., González del Tánago, J., and Dunning, G., 1999a, Tectonic evolution of the Careón ophiolite (Northwest Spain): A remnant of oceanic lithosphere in the Variscan belt: The Journal of Geology, v. 107, p. 587-605.

Díaz García, F., Martínez Catalán, J.R., Arenas, R., and González Cuadra, P., 1999b, Structural and kinematic analysis of the Corredoiras Detachment: evidence for early variscan orogenic extension in the Ordenes Complex, NW Spain: International Journal of Earth Sciences, v. 88, p. 337-351.

Díez Balda, M.A., Martínez Catalán, J.R., and Ayarza, P., 1995, Syn-collisional extensional collapse parallel to the orogenic trend in a domain of steep tectonics: the Salamanca detachment zone (Central Iberian zone, Spain): Journal of Structural Geology, v. 17, p. 163-182.

Escuder Viruete, J., Arenas, R., and Martínez Catalán, J.R., 1994, Tectonothermal evolution associated with Variscan crustal extension in the Tormes Gneiss Dome (NW Salamanca, Iberian Massif, Spain): Tectonophysics, v. 238, p. 117-138. 
Farias, P., Gallastegui, G., González-Lodeiro, F., Marquínez, J., Martín Parra, L.M., Martínez Catalán, J.R., Pablo Maciá, J.G. de, and Rodríguez Fernández, L.R., 1987, Aportaciones al conocimiento de la litoestratigrafía y estructura de Galicia Central: Memórias da Faculdade de Ciências, Universidade do Porto, v. 1, p. 411-431.

Fernández-Suárez, J., Corfu, F., Arenas, R., Marcos, A., Martínez Catalán, J.R., Díaz García, F., Abati, J., and Fernández, F.J., 2002, U-Pb evidence for a polyorogenic evolution of the $\mathrm{H} P$-HT units of the NW Iberian Massif: Contributions to Mineralogy and Petrology, v. 143, p. 236-253.

Fortey, R.A., and Cocks, L.R.M., 1988, Arenig to Llandovery faunal distributions in the Caledonides, in Harris, A.L., and Fettes, D.J., eds., The Caledonian-Appalachian Orogen: London, Geological Society of London Special Publication 38, p. 233-246.

Franke, W., 1989, Tectonostratigraphic units in the Variscan belt of central Europe, in Dallmeyer, R.D., ed., Terranes in the Circum-Atlantic Paleozoic Orogens: Boulder, Colorado, Geological Society of America Special Paper 230, p. 67-90.

Frisch, W., and Neubauer, F., 1989, Pre-Alpine terranes and tectonic zoning in the eastern Alps, in Dallmeyer, R.D., ed., Terranes in the Circum-Atlantic Paleozoic Orogens: Boulder, Colorado, Geological Society of America Special Paper 230, p. 91-100.

García Garzón, J., Pablo Maciá, J.G. de, and Llamas Borrajo, J.F., 1981, Edades absolutas obtenidas mediante el método $\mathrm{Rb} / \mathrm{Sr}$ en dos cuerpos de ortoneises en Galicia Occidental: Boletín Geológico y Minero de España, v. 92, p. $463-466$.

Gates, A.E., Simpson, C., and Glover III, L., 1986, Appalachian Carboniferous dextral strike-slip faults: an example from Brookneal, Virginia: Tectonics, v. 5 , p. 119-133.

Gebauer, D., 1993, Intra-grain zircon dating within the Iberian Massif: Ollo de Sapo augengneisses, bimodal gneisses from the Massif de Guilleries (Girona), graywacke of the Tentudía Group (Serie Negra, SW Spain) and the high- $P$ /high- $T$-rock association at Cabo Ortegal (Galicia): Comunicações XII Reunião de Geologia do Oeste Peninsular, Universidade de Evora, v. 2, p. 41-46.

Gil Ibarguchi, J.I., Mendia, M., Girardeau, J., and Peucat, J.J., 1990, Petrology of eclogites and clynopiroxene-garnet metabasites from the Cabo Ortegal Complex (northwestern Spain): Lithos,v. 25, p. 133-162.

Girardeau, J., and Gil Ibarguchi, I., 1991, Pyroxenite-rich peridotites of the Cabo Ortegal Complex (Northwestern Spain): Evidence for large-scale uppermantle heterogeneity: Journal of Petrology, v. 32 (Special Lherzolites Issue), p. 135-154.

González Cuadra, P., Martínez Catalán, J.R., Arenas, R., Díaz García, F., and Abati, J., 1999, Polyorogenic evolution of the Uppermost units of the Ordenes Complex (NW Spain): Journal of Conference Abstracts, European Union of Geosciences 10, p. 34.

Gutiérrez-Alonso, G., Barba, P., and Díaz García, F., 2000, Sedimentology and structure of the low grade uppermost unit of the Ordenes Complex at the coastal section. Superposition of structural trends and processes: Variscan-Appalachian dynamics: the building of the Upper Paleozoic basement, Basement Tectonics 15: A Coruña, Spain, Program and Abstracts, p. 234-235.

Hatcher, R.D., Jr., 1989, Tectonic synthesis of the U.S. Appalachians, in Hatcher, R.D., Thomas, W.A., and Viele, G.W., eds., The Appalachian-Ouachita Orogen in the united States: Boulder, Colorado, Geological Society of America, Geology of North America, v. F-2, p. 511-535.

Hatcher, R.D., Jr., 2001, Rheological partitioning during multiple reactivation of the Paleozoic Brevard fault zone, Southern Appalachians, USA, in Holdsworth, R.E., Strachan, R.A., Magloughlin, J.F., and Knipe, R.J., eds., The nature and tectonic significance of fault zone weakening: London, Geological Society of London Special Publication 186, p. $257-$ 271.

Hibbard, J.P., and Samson, S.D., 1995, Orogenesis exotic to the Iapetan cycle in the southern Appalachians. in Hibbard, J.P., Van Staal, C.R., and Cawood, P.A., eds., Current perspectives in the Appalachian-Caledonian Orogen: Geological Association of Canada Special Paper 41, p. 191-205.
Hilgen, J.D., 1971, The Lalín unit: a new structural element in the Hercynian Orogen of Galicia (NW Spain): Koninklijke Nederlandse Akademie van Wetenschappen, Amsterdam, Series B, v. 74, p. 398-407.

Holdaway, M.J., 1971, Stability of andalusite and the aluminum silicate phase diagram: American Journal of Science, v. 271, p. 97-131.

Hossack, J.R., and Cooper, M.A., 1986, Collision tectonics in the Scandinavian Caledonides, in Coward, M.P., and Ries, A.C., eds., Collision tectonics: London, Geological Society of London Special Publication 19, p. 287-304. Hubregtse, J.J. M.V., 1973, High-grade metamorphic rocks of the Mellid area, Galicia, N.W. Spain: Leidse Geologische Mededelingen, v. 49, p. 9-31.

Hutton, D.H. W., 1989, Pre-Alleghanian terrane tectonics in the British and Irish Caledonides, in Dallmeyer, R.D., ed., Terranes in the Circum-Atlantic Paleozoic Orogens: Boulder, Colorado, Geological Society of America Special Paper 230, p. 67-90.

Jamieson, R.A., 1986, $P-T$ paths from high temperature shear zones beneath ophiolites: Journal of Metamorphic Geology, v. 4, p. 3-22.

Keen, C., Peddy, C., de Voogd, B., and Matthews, D., 1989, Conjugate margins of Canada and Europe: Results from deep reflection profiling: Geology, v. 17 , p. $173-176$.

Keppie, J.D., 1989, Northern Appalachian terranes and their accretionary history, in Dallmeyer, R.D., ed., Terranes in the Circum-Atlantic Paleozoic Orogens: Boulder, Colorado, Geological Society of America Special Paper 230, p. $159-192$.

Kuijper, R.P., 1980, Precambrian U-Pb zircon ages from Western Galicia (NW Spain): Earth-Science Reviews, v. 16, p. 313-316.

Lancelot, J.R., Allegret, A., and Iglesias-Ponce de León, M., 1985, Outline of Upper Precambrian and lower Paleozoic evolution of the Iberian Peninsula according to U-Pb dating of zircons: Earth and Planetary Science Letters, v. 74, p. 325-337.

Lefort, J.P., 1989, Basement correlation across the north Atlantic: Berlin, Germany, Springer-Verlag, $148 \mathrm{p}$.

Liñán, E., and Quesada, C., 1990, Ossa-Morena zone: Stratigraphy, rift phase (Cambrian), in Dallmeyer, R.D., and Martínez García, E., eds., Pre-Mesozoic geology of Iberia: Berlin, Germany, Springer-Verlag, p. 259-266.

Marcos, A., 1973, Las Series del Paleozoico Inferior y la estructura herciniana del occidente de Asturias (NW de España): Trabajos de Geología, Universidad de Oviedo, v. 6, p. 1-113.

Marcos, A., Marquínez, J., Pérez-Estaún, A., Pulgar, J.A., and Bastida, F., 1984, Nuevas aportaciones al conocimiento de la evolución tectonometamórfica del Complejo de Cabo Ortegal (NW de España): Cuadernos do Laboratorio Xeolóxico de Laxe, v. 7, p. 125-137.

Marquínez García, J.L., 1984, La geología del área esquistosa de Galicia Central (Cordillera Herciniana, NW de España): Memorias del Instituto Geológico y Minero de España, v. 100, 231 p.

Martínez Catalán, J.R., and Arenas, R., 1992, Deformación extensional de las unidades alóctonas superiores de la parte oriental del Complejo de Ordenes (Galicia): Geogaceta, v. 11, p. 108-111.

Martínez Catalán, J.R., Arenas, R., Díaz García, F., and Abati, J., 1997, Variscan acretionary complex of northwest Iberia: Terrane correlation and succession of tectonothermal events: Geology, v. 25, p. 1103-1106.

Martínez Catalán, J.R., Arenas, R., Díaz García, F., and Abati, J., 1999, Allochthonous units in the Variscan belt of NW Iberia. Terranes and accretionary history, in Sinha, A.K., ed., Basement Tectonics 13: Dordrecht, Netherlands, Kluwer, p. 65-84.

Martínez Catalán, J.R., Arenas, R., Díaz García, F., Rubio Pascual, F.J., Abati, J., and Marquínez, J., 1996, Variscan exhumation of a subducted Paleozoic continental margin: The basal units of the Ordenes Complex, Galicia, NW Spain: Tectonics, v. 15, p. 106-121.

Martínez Catalán, J.R., Klein, E., Pablo Maciá, J.G., and González Lodeiro, F., 1984, El Complejo de Ordenes: subdivisión, descripción y discusión sobre su origen: Cuadernos do Laboratorio Xeolóxico de Laxe, v. 7, p. 139-210.

Matte, Ph., 1968, La structure de la virgation hercynienne de Galice (Espagne): Revue de Géologie Alpine, v. 44, p. 1-128.

Matte, Ph., and Capdevila, R., 1978, Tectonique en grands plis couchés et plissements superposés d'âge hercynien dans la série de Ordenes-Betanzos (Gal- 
ice Occidentale): Coruña, Spain, Cuadernos del Seminario de Estudios Cerámicos de Sargadelos, v. 27, p. 193-201.

Mendia Aranguren, M.S., 1996, Petrología de la Unidad Eclogítica del Complejo de Cabo Ortegal (NW de España) [Ph.D. thesis]: Bilbao, Spain, Universidad del País Vasco, 463 p.

Mitra, G., and Boyer, S.E., 1986, Energy balance and deformation mechanisms of duplexes: Journal of Structural Geology, v. 8, p. 291-304.

Murphy, J.B., Nance, R.D., Keppie, J.D., Dostal, J., and Cousens, B.L., 1995, Odyssey of West Avalonia: Isotopic constraints for Late Proterozoic III-Early Silurian Paleogeography, in Hibbard, J.P., Van Staal, C.R., and Cawood P.A., eds., Current perspectives in the Appalachian-Caledonian orogen: Geological Association of Canada Special Paper 41, v. 227-237.

Murphy, J.B., and Nance, R.D., 1991, Supercontinent model for the contrasting character of late Proterozoic orogenic belts: Geology, v. 19, p. 469-472.

Neuman, R.B., and Max, M.D., 1989, Penobscottian-Grampian-Finnmarkian orogenies as indicators of terrane linkages, in Dallmeyer, R.D., ed., Terranes in the Circum-Atlantic Paleozoic Orogens: Boulder, Colorado, Geological Society of America Special Paper 230, p. 31-45.

Ochsner, A., 1993, U-Pb geochronology of the Upper Proterozoic-Lower Paleozoic geodynamic evolution in the Ossa-Morena zone (SW Iberia): Constraints on the timing of the Cadomian orogeny [Ph.D. thesis]: Zurich, Switzerland, Swiss Federal Institute of Technology, 249 p.

Ohta, Y., Dallmeyer, R.D., and Peucat, J.J., 1989, Caledonian terranes in Svalbard, in Dallmeyer, R.D., ed., Terranes in the Circum-Atlantic Paleozoic Orogens: Boulder, Colorado, Geological Society of America Special Paper 230, p. 1-15.

Ordóñez Casado, B., Gebauer, D., Schäfer, H.J., Gil Ibarguchi, J.I., and Peucat, J.J., 2001, A single Devonian subduction event for the HP/HT metamorphism of the Cabo Ortegal complex within the Iberian Massif: Tectonophysics, v. 332, p. 359-385.

Osberg, P.H., Tull, J.F., Robinson, P., Hon, R., and Butler, J.R., 1989, The Acadian Orogeny, in Hatcher, R.D., Thomas, W.A., and Viele, G.W., eds., The Appalachian-Ouachita Orogen in the United States: Boulder, Colorado, Geological Society of America, Geology of North America, v. F-2, p. $179-232$.

Pérez-Estaún, A., Martínez Catalán, J.R., and Bastida, F., 1991, Crustal thickening and deformation sequence in the footwall to the suture of the Variscan Belt of northwest Spain: Tectonophysics, v. 191, p. 243-253.

Peucat, J.J., Bernard-Griffiths, J., Gil Ibarguchi, J.I., Dallmeyer, R.D., Menot, R.P., Cornichet, J., and Iglesias Ponce de León, M., 1990, Geochemical and geochronological cross section of the deep Variscan crust: The Cabo Ortegal high-pressure nappe (northwestern Spain): Tectonophysics, v. 177, p. 263-292.

Pin, C., Ortega Cuesta, L.A., and Gil Ibarguchi, J.I., 1992, Mantle-derived, early Paleozoic A-type metagranitoids from the NW Iberian Massif: Nd isotope and trace-element constraints: Bulletin de la Societé Géologique de France, v. 163 , p. $483-494$.

Quinlan, G.M., Hall, J., Williams, H., Wright, J.A., Colman-Sadd, S.P., O'Brien, S.J., Stockmal, G.S., and Marillier, F., 1992, Lithoprobe onshore seismic reflection transects across the Newfoundland Appalachians: Canadian Journal of Earth Sciences, v. 29, p. 1865-1877.

Ribeiro, M.L., and Floor, P., 1987, Magmatismo peralcalino no Maciço Hespérico: Sua distribução e significado geodinámico, in Bea, F., Carnicero, A., Gonzalo, J.C., López-Plaza, M., and Rodríguez Alonso, M.D., eds., Geología de los granitoides y rocas asociadas del Macizo Hespérico: Madrid, Spain, Rueda, p. 211-221.

Ribeiro, A., Dias, R., and Brandao Silva, J., 1995, Genesis of the Ibero-Armorican arc: Geodinamica Acta, v. 8, p. 173-184.
Ribeiro, A., Pereira, E., and Dias, R., 1990, Central-Iberian zone . Allochthonous Sequences. Structure in the northwest of the Iberian Peninsula, in Dallmeyer, R.D., and Martínez García, E., eds., Pre-Mesozoic geology of Iberia: Berlin, Germany, Springer-Verlag, p. 220-236.

Ries, A.C., 1979, Variscan metamorphism and K-Ar dates in the Variscan fold belt of south Brittany and NW Spain: Journal of the Geological Society of London, v. 136, p. 89-103.

Ries, A.C., and Shackleton, R.M., 1971, Catazonal complexes of northwest Spain and north Portugal remnants of a Hercynian thrust plate: Nature Physical Sciences, v. 234, p. 65-69.

Santos Zalduegui, J, F., Schärer, U., and Gil Ibarguchi, J.I., 1995, Isotope constraints on the age and origin of magmatism and metamorphism in the Malpica-Tuy allochthon, Galicia, NW-Spain: Chemical Geology, v. 121, p. 91-103.

Santos Zalduegui, J.F., Schärer, U., Gil Ibarguchi, J.I., and Girardeau, J., 1996, Origin and evolution of the Paleozoic Cabo Ortegal ultramafic-mafic complex (NW Spain): U-Pb, Rb-Sr and Pb-Pb isotope data: Chemical Geology, v. 129, p. 281-304.

Schäfer, H.J., Gebauer, D., Gil Ibarguchi, J.I., and Peucat, J.J., 1993, Ion-microprobe U-Pb zircon dating on the HP/HT Cabo Ortegal Complex (Galicia, NW Spain): preliminary results: Terra Abstracts, v. 5.4, p. 22.

Soper, N.J., 1988, Timing and geometry of collision, terrane accretion and sinistral strike-slip events in the British Caledonides, in Harris, A.L., and Fettes, D.J., eds., The Caledonian-Appalachian Orogen: London, Geological Society of London Special Publication 38, p. 481-492.

Valverde Vaquero, P., and Fernández, F.J., 1996, Edad de enfriamiento U/Pb en rutilos del Gneis de Chímparra (Cabo Ortegal, NO de España): Geogaceta, v. 20, p. 475-478.

Van Calsteren, P.W.C., Boelrijk, N.A.I.M., Hebeda, E.H., Priem, H.N.A., den Tex, E., Verdurmen, E.A.T.H., and Verschure, R.H., 1979, Isotopic dating of older elements (including the Cabo Ortegal mafic-ultramafic complex) in the Hercynian Orogen of NW Spain: manifestations of a presumed Early Paleozoic Mantle-plume: Chemical Geology, v. 24, p. 35-56.

Van Zuuren, A., 1969, Structural petrology of an area near Santiago de Compostela (NW Spain): Leidse Geologische Mededelingen, v. 45, p. 1-71.

Vogel, D.E., 1967, Petrology of an eclogite- and pyrigarnite-bearing polymetamorphic rock Complex at Cabo Ortegal, NW Spain: Leidse Geologische Mededelingen, v. 40, p. 121-213.

Von Raumer, J.F., and Neubauer, F., 1993, Late Precambrian and Paleozoic evolution of the Alpine basement-An overview, in Von Raumer, J.F., and Neubauer, F., eds., Pre-Mesozoic geology in the Alps: Berlin, Germany, Springer-Verlag, p. 625-639.

Von Raumer, J.F., Stampfli, G.M., Borel, G., and Bussy, F., 2001, The organization of pre-Variscan Basement areas at the Gondwana margin: International Journal of Earth Sciences, v. 91, p. 35-52.

Winchester, J.A., and Van Staal, C.R., 1995, Volcanic and sedimentary terrane correlation between Dunnage and Gander zones of the Canadian Appalachians and the British Caledonides reviewed, in Hibbard, J.P., Van Staal, C.R., and Cawood, P.A., eds., Current perspectives in the Appalachian-Caledonian Orogen: Geological Association of Canada Special Paper 41, p. 95-114.

Yardley, B.W.D., 1989, An introduction to metamorphic petrology: New York, USA, Longman Scientific and Technical, 248 p. 

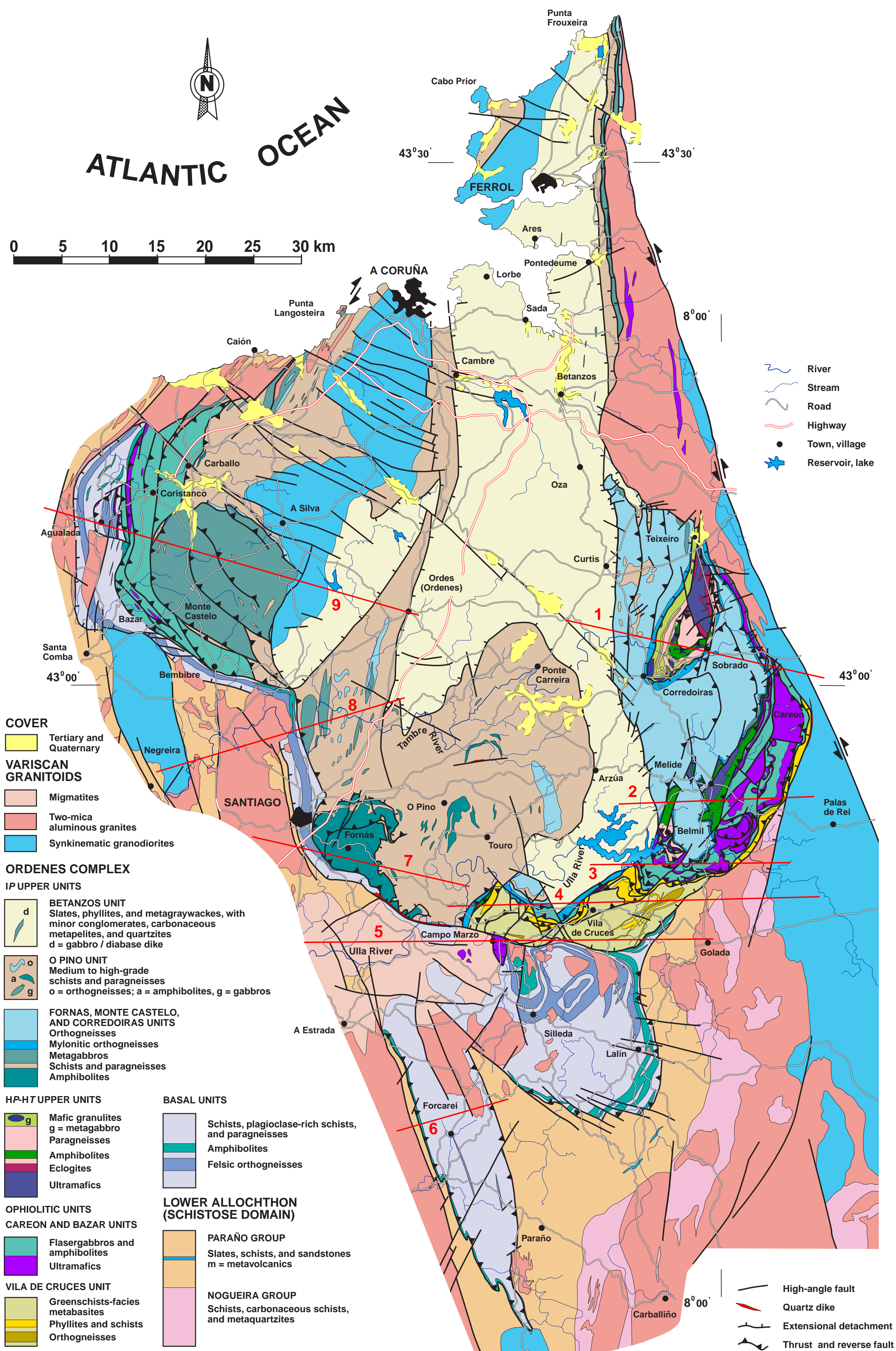

Plate 2. Geological map of Ordenes Complex (northwestern Spain). 


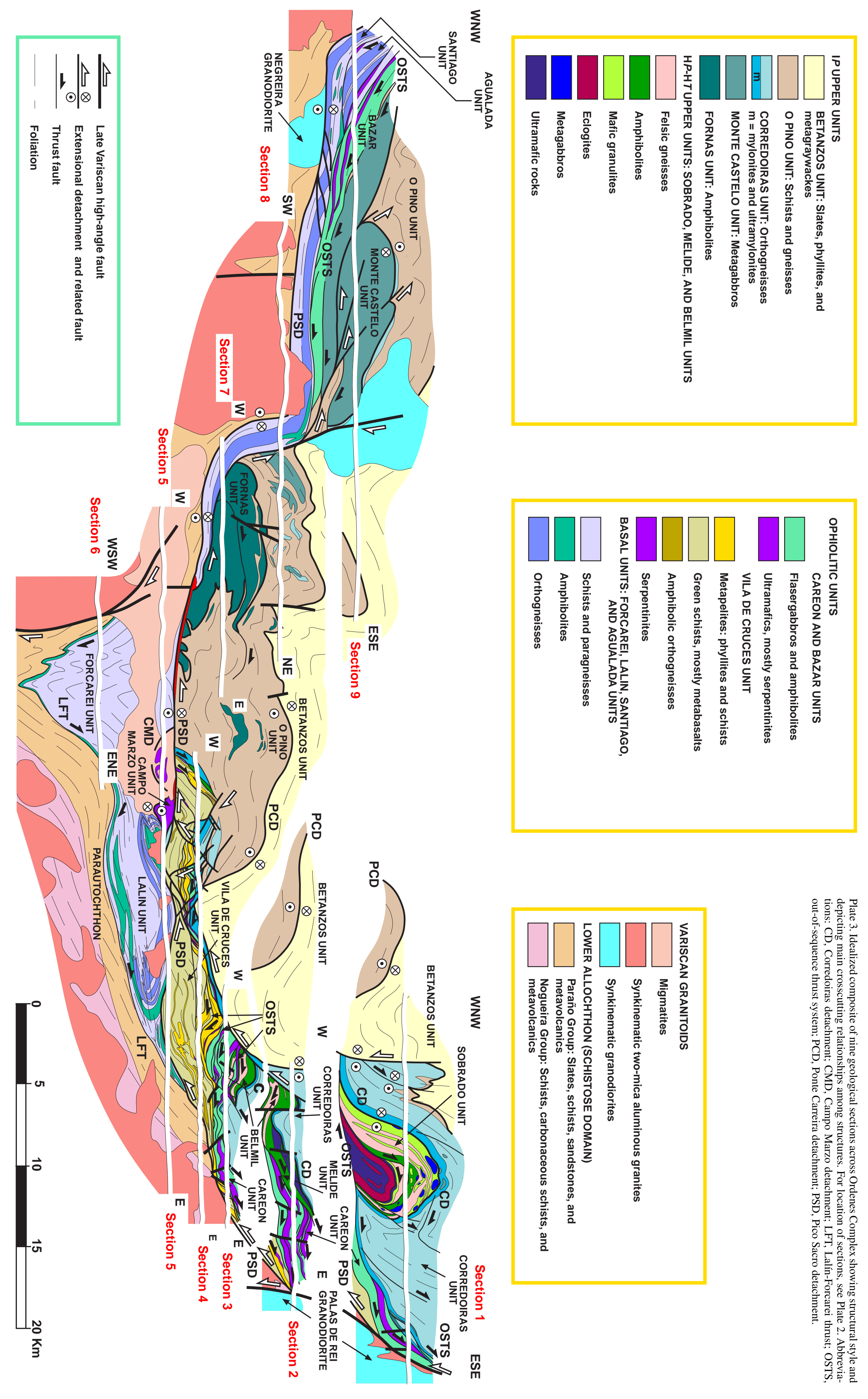

